\title{
A rising tide of adaptation action: Comparing two coastal regions of Aotearoa-New Zealand
}

\author{
Paul Schneider ${ }^{\mathrm{a}, *}$, Judy Lawrence ${ }^{\mathrm{b}}$, Bruce Glavovic ${ }^{\mathrm{a}}$, Emma Ryan ${ }^{\mathrm{c}}$, Paula Blackett ${ }^{\mathrm{d}}$ \\ ${ }^{\text {a }}$ School of People, Environment and Planning, Massey University, New Zealand \\ ${ }^{\mathrm{b}}$ Climate Change Research Institute, Victoria University of Wellington, New Zealand \\ c School of Environment, The University of Auckland, New Zealand \\ ${ }^{\mathrm{d}}$ National Institute of Water and Atmospheric Research (NIWA), New Zealand
}

\section{A R T I C L E I N F O}

\section{Keywords:}

Coastal hazard risk

Climate risk

Adaptation

Barriers

Enablers

Aotearoa-New Zealand

Hawke's Bay

Coromandel Peninsula

\begin{abstract}
A B S T R A C T
Diverse and contested local interests and the complexity of climate change make adaptation to climate change risks at the coast challenging. Even in similar settings, adaptation experiences and prospects can differ markedly. Why? This paper provides empirical evidence of comparative adaptation experiences in two regions of Aotearoa-New Zealand - the Coromandel Peninsula and the Hawke's Bay coast. We critically examine how local barriers and enablers influence the trajectory of adaptation in two regions that face similar risks, have essentially the same institutional architecture, and yet have had very different adaptation experiences. We investigate the situational differences and similarities, and their implications for adaptation in each region. We found that the evolution of adaptation is shaped by the perceptions of the actors, especially local authority leaders, and opportunities that arise at a context-specific point in time. Such perceptions and opportunities can amount to barriers in one location and enablers in another. Growing concern about coastal hazard risk, improving levels of trust and legitimacy, community engagement, and collaborative governance were key to innovative long-term adaptation planning in the Hawke's Bay but their absence has led to short-term business as usual practices in the Coromandel. Yet even in the latter case, change is underway and longer-term adaptation planning is commencing. We conclude that there is a 'rising tide' of adaptation action in the face of escalating climate risk - with long-term planning and local action triggered by cumulative hazard experience and / or extreme events that raise public concern and make climate change salient to local community members and leaders. Both local and regional interests and concerns shape local response appetites. Proactive, local authority-led engagement and long-term strategic planning are foundational for mobilizing effective adaptation responses. Enabling national policy, guidance and institutional provisions are key to prompting and sustaining such efforts, and to facilitating broad consistency in locally appropriate responses. Notwithstanding efforts to foster locally appropriate but nationally aligned adaptation responses, our research shows that coastal communities and their local authorities follow pathways consistent with local risk appetites, understanding about climate change, and the political will and capacity of local government to mobilize key governance actors around long-term strategic planning.
\end{abstract}

\footnotetext{
* Corresponding author.

E-mail address: p.p.schneider@massey.ac.nz (P. Schneider).
} 


\section{Introduction}

Escalating climate-related impacts and risks are already a lived reality for many coastal communities and effective adaptation responses will be necessary for the foreseeable future (Barnett et al., 2015; Eisenack et al., 2014; Glavovic, Kelly, Kay, \& Travers, 2014; Lawrence et al., 2015; Manning, Lawrence, King, \& Chapman, 2015; Moser, 2013). Adaptation barriers and enablers are, however, unevenly distributed within and between regions, countries and communities, and across different time periods (Klein et al., 2014). Deeper understanding about barriers to adaptation can shed light on the types of intervening action that are possible, and necessary, in a particular locality at a given point in time (Adger et al., 2009; Berrang-Ford, Pearce, \& Ford, 2015; Biesbroek, Klostermann, Termeer, \& Kabat, 2013), and could lead to ongoing reflexive adaptation (Glavovic et al., 2014; Haverkamp, 2017; Preston, Mustelin, \& Maloney, 2015; Westling et al., 2019). Here we focus on the factors shaping adaptation action (or inaction) in the face of escalating coastal hazard risk in Aotearoa-New Zealand. In particular, we examine experiences in two different regions - the Coromandel Peninsula and the Hawke's Bay coast (Fig. 1) - that share similar coastal hazard risks and socio-economic, institutional and cultural characteristics but have taken markedly different adaptation pathways, intentionally or otherwise. What drives such divergent responses, and how are adaptation barriers and enablers understood and addressed in practice in apparently similar settings?

To address this question we first review the literature to understand how barriers and enablers influence adaptation experiences and prospects in coastal settings, and to frame the study approach. Second, we describe the research methods used to carry out this study. Third, we describe the institutional setting within which the Hawke's Bay and Coromandel Peninsula are situated. Fourth, we describe these regional settings. Fifth, we present findings from key informant interviews and focus group discussions. Sixth, we discuss these findings according to emergent key themes in relation to insights from the literature review, and in the light of recent studies on adaptation in Aotearoa-New Zealand (Lawrence et al., 2015; Manning et al., 2015; Reisinger, Lawrence, Hart, \& Chapman, 2015; Rouse et al., 2017; Schneider \& Glavovic, 2019; Schneider, Glavovic, \& Farrelly, 2017). The final section presents conclusions
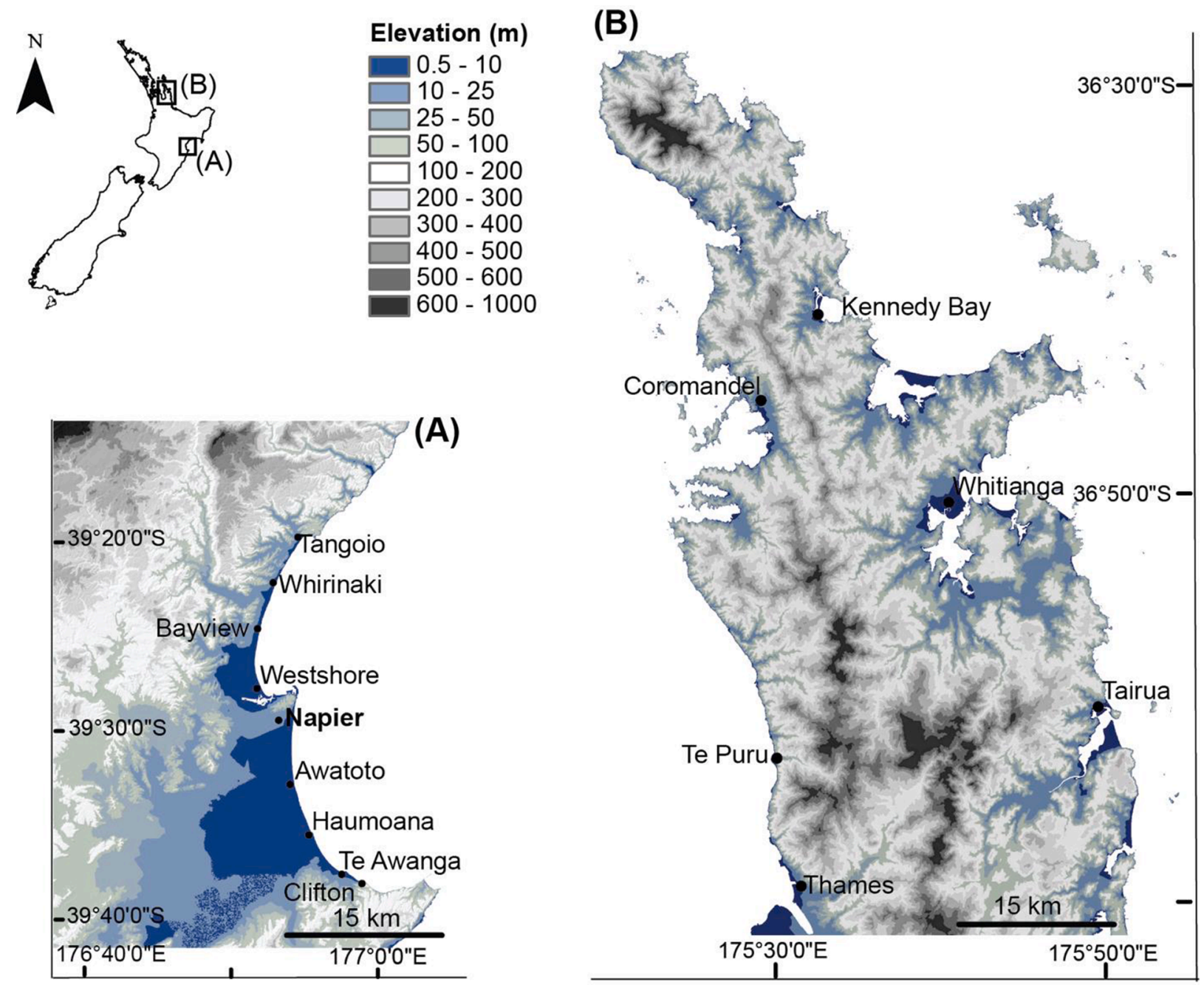

Fig. 1. The Hawke's Bay (A) and the Coromandel (B) regions. 
and recommendations.

\section{Barriers and enablers to adaptation}

Literature on barriers to adaptation indicates that barriers can be overcome with concerted effort (Moser \& Ekstrom, 2010; Waters, Barnett, \& Puleston, 2014) and that failure to do so delays adaptation decision-making (Termeer, Dewulf, Karlsson-Vinkhuyzen, Vink, \& Vliet, 2016) which is problematic given the "escalating costs and risks of delayed action", especially at the coast (IPCC, 2019, p. 1). Adaptation unfolds over time as the climate changes; it is dynamic and constantly evolving (Viner et al., 2020). Furthermore, climate change compounds the coastal hazard risk regime (Collins et al., 2019; Oppenheimer et al., 2019) making closer integration of disaster risk management and adaptation compelling (Birkland, 2016b; IPCC, 2012).

The way enabling conditions are set up, and how coastal hazard risks and impacts are perceived by the people impacted, and those empowered with the authority to act at different levels of government, influence the nature, initiation, and duration of local adaptation planning and action (Eisenack et al., 2014; Lawrence et al., 2015). For example, without enabling adaptation provisions at the national level, action at the regional and local levels can be hampered by narrowly framed local interests (Amundsen, Berglund, \& Westskog, 2010).

Credibility, salience and legitimacy are key enabling conditions for translating knowledge into enduring action (Cash et al., 2003). Credibility refers to the scientific adequacy of evidence and arguments; salience is the relevance of information for decision-makers; and legitimacy "reflects the perception that the production of information [...] has been respectful of stakeholder's divergent values and beliefs, unbiased in its conduct, and fair in its treatment of opposing views and interests" (Cash et al., 2003, p. 8086). These characteristics need to be simultaneously present to bridge knowledge and action (ibid.) but narrowing the "climate information usability gap" is neither easy nor straightforward (Lemos, Kirchhoff, \& Ramprasad, 2012, p. 789). The usability of climate information depends on users perceiving that the information 'fits' the problem at hand; how new knowledge 'interplays' with other types of knowledge drawn on by users; and the level and quality of producer-user 'interactions' (ibid.). Trust building and accountability between producers and users is key to improving perceptions of climate information credibility, salience and legitimacy (ibid.).

Community engagement is widely considered an essential ingredient in coastal hazard risk reduction and adaptation planning (Berke \& Stevens, 2016; Lawrence et al., 2019a; Rouse et al., 2017; Serrao-Neumann et al., 2015b). In practice, the ideal of public participation is far from easy to achieve (Arnstein, 1969; IAP2, 2018; Reed, 2008). Invariably, governing authorities need to work closely with citizens and stakeholders to craft practical processes that secure broad support (Uittenbroek, Mees, Hegger, \& Driessen, 2019). Community engagement in public decision-making is an integral part of governance in the public arena - in which actors from government, civil society and the private sector interact to make social choices (Kooiman, 2003).

Governance is a highly ranked adaptation barrier (Biesbroek, Klostermann, Termeer, \& Kabat, 2011), in particular, the barrier of fragmentation within and between spheres of government (Amundsen et al., 2010). Local leadership also strongly influences the way adaptation unfolds over time (Termeer, Dewulf, \& Biesbroek, 2017; Termeer et al., 2011). A deeper understanding of institutional capacities and configurations is necessary to reveal how leadership and the adaptive capacity of actors might inhibit or catalyse and mobilise adaptation (Lawrence et al., 2015). Adaptive institutions use reflexive, resilient, responsive, revitalizing and rescaling strategies (Termeer et al., 2016) and navigate multiple governance levels to overcome barriers, create enablers, and prevent lags in adaptation (Amundsen et al., 2010; Araos, Ford, Berrang-Ford, Biesbroek, \& Moser, 2017). Also important are the prevailing politics at different scales of governance; dominant values that are reflected in local decisions and actions; the 'appetite' for addressing coastal hazard risks; prevailing governance frameworks; and the ability of decision makers to develop and implement sustainable risk management strategies (Duijnhoven \& Neef, 2016) and to fund adaptation (Boston \& Lawrence, 2018). Such governance and institutional considerations are widely recognised as being key to enabling adaptation (Adger, 2001; Burch, 2010; Dovers \& Hezri, 2010; Naess, Bang, Eriksen, \& Vevatne, 2005).

Our review of literature on adaptation barriers and enablers in the face of escalating coastal hazard risk reveals four key points that helped to frame this study:

1) Overcoming barriers does not automatically translate into enablers (Biesbroek et al., 2013; Biesbroek, Termeer, Klostermann, \& Kabat, 2014a; Burch, 2010) - hence the need to better understand the nature of and interactions between barriers and enablers in practice.

2) Multilevel governance influences the initiation and outcome of local adaptation efforts (Juhola, 2016; Lawrence et al., 2015; Waters \& Barnett, 2017) - but how does the interaction between levels of governing authority unfold in practice; and how might locally relevant responses be enabled in a coherent manner within and between regions (at the sub-national scale)?

3) Local institutions and context have a strong bearing on barriers and enablers, and the ways they constrain and shape adaptation over time (Amundsen et al., 2010; Barnett et al., 2015; Biesbroek, Termeer, Klostermann, \& Kabat, 2014b; Fazey et al., 2016; Oberlack, 2017; Walker, Adger, \& Russel, 2014) - hence the value of comparing experiences in settings that share common features to better understand what drives different adaptation responses over time.

4) Focussing climate events create windows of opportunity for change (IPCC, 2012) - hence the need to probe the ways in which hazard experience and extreme events influence adaptation responses by coastal communities and their governing authorities.

This study examines these issues by comparing recent experience in the Coromandel Peninsula and the Hawke's Bay coast in Aotearoa-New Zealand - two regions that share many similar features but have embarked on very different adaptation pathways. We explore why responses differ, and how adaptation barriers and enablers are understood and addressed in practice. We reveal how 
coastal hazard risks are perceived by those empowered to act, how barriers and enablers are framed and how they shape adaptation actions and their timing, given the influence by locality-specific circumstances.

\section{Research methods}

This study was part of two complementary research initiatives: the Hawke's Bay research formed part of a National Science Challenge project 'Living at the Edge', which contributed to and observed a community-focused decision-making process led by local government to develop a coastal hazards strategy for long-term community resilience - the Clifton to Tangoio Coastal Hazards Strategy $2120^{2}$ (Strategy) (OECD, 2019). The Coromandel research was based on post-doctoral research seeking to understand local barriers to hazard risk reduction and resilience building. There were common research personnel across both research initiatives, which provided the opportunity to compare the dynamic local processes, barriers, enablers and adaptation processes and outcomes in both regions. A Community Based Participatory Research approach (Cvitanovic et al., 2019) was used in both research initiatives, "giving voice" to local stakeholder insights on coastal hazard risk and barriers and enablers for developing effective strategies to reduce risk. The research in Hawke's Bay was undertaken using a co-creation process with the research team playing a "critical friend ${ }^{3}$ role alongside those agencies responsible for developing the Strategy (Kench et al., 2018). In the Coromandel region, the research was grounded in a decade-long, and ongoing, ethnographic adaptation study (Schneider \& Glavovic, 2019).

In the Hawke's Bay, trust was built between researchers, local authorities, and community stakeholders through 18 months of sustained interaction between the researchers, governing authorities and stakeholders in 2016 and 2017 (Kench et al., 2018 ). To understand the barriers and enablers influencing the Strategy development and whether they changed in the process, 21 one-on-one key informant interviews were conducted in total, first in 2016 and again in 2018 with the same interviewees. Focus groups were also held, and participant observation was used to assess how the Strategy development process, and associated assessment tools used, influenced the adaptation process and outcomes (Lawrence et al., 2019a). Interviewees comprised elected councillors, technical council staff from planning and engineering, community members from directly affected areas and from the wider community, as well as representatives from regional asset companies (airport and port), and cultural and coastal engineering advisors. All interviews were conducted at the same neutral location using open-ended questions. Five of the 21 interviews were undertaken by phone, due to participant availability (see supplementary material).

In the Coromandel region, the first author had built trust with many key stakeholders during a decade of research on the "local reality and the climate change adaptation dilemma" and on "contrasting climate change perceptions" (Schneider, 2014; Schneider \& Glavovic, 2019). The Coromandel interviews were conducted to understand how risk governance, resilience planning and coastal adaptation were being undertaken; with 19 interviews conducted between February and April 2018. Participants included elected councillors/local politicians, local and regional council staff, community members and technical planning and engineering staff. Interviews were conducted at locations selected by research participants, based on five open-ended questions comparable with the questions used in Hawkes Bay (see supplementary material).

All interviews were recorded, transcribed and thematically analysed for commonalities and differences between adaptation experiences in the two regions. Braun and Clarke's (2014) six-phase approach to thematic analysis was used, comprising (i) data familiarisation, (ii) initial sorting of issues for code generation, (iii) the identification of themes, (iv) the review of themes, (v) the definition of themes and finally (vi) the identification of research findings.

Local media reports on coastal issues and climate change adaptation were screened to identify key events and issues potentially influencing perceptions and risk reduction and adaptation choices over time in both regions (see supplementary material). The media data were generated based on newspaper articles sourced through Stuff.co.nz, or relevant articles in a Stuff.co.nz catalogue search using the search terms "Hawke's Bay climate change" and "Coromandel climate change" from January 2009 to December 2019. Stuff. co.nz was selected as a representative media platform based on its extensive circulation, being Aotearoa-New Zealand's highest ranking news site (Alexa, 2019). A total of 27 and 29 articles for the Hawke's Bay and Coromandel respectively were identified as relevant to this research. The media reports provide context and insights about the evolving nature of coastal risk perceptions and experiences. They are presented in the sections below on institutional context and regional settings.

\section{Institutional context}

Coastal hazard risk management in Aotearoa-New Zealand is governed principally through the Resource Management Act 1991 (RMA), which comprises a hierarchy of regulatory provisions that guide how coastal hazards should be addressed. The RMA identifies the management of significant natural hazard risk as a matter of national significance and requires local government to "have regard to the effects of climate change" (RMA section 7 (i)). Several other statutes relevant to coastal hazard risk management and adaptation to climate change include the Local Government Act 2002 (LGA) (with provisions for community wellbeing, Long Term Plans and

\footnotetext{
${ }^{1}$ https://resiliencechallenge.nz/edge/

2 https://www.hbcoast.co.nz/

3 Akin to an amicus curiae role assisting a court.
} 
community engagement including with Māori as tangata whenua of New Zealand ${ }^{4}$ ), the Local Government Official Information and Meetings Act 1987 (includes Land Information Memoranda for matters, including hazards, that affect private property), the Building Act 2004 and Building Code (addressing the safety of buildings and flood standards), and the Civil Defence Emergency Management (CDEM) Act 2002 (including provisions for national and regional preparedness, disaster response, recovery and risk reduction).

The past decade has witnessed significant natural hazard events, the publication of key reports and policy actions that shape the way natural hazard risk is understood and addressed in Aotearoa-New Zealand (Fig. 2). Their combined impact means that natural hazard risks, and coastal hazard risk in particular, have become prominent in public, political and policy discourses; and local councils throughout Aotearoa-New Zealand are paying closer attention to climate change adaptation.

Implementation of legislation is supported by national level policies, principally the New Zealand Coastal Policy Statement (NZCPS) 2010, which was first promulgated in 1991 under the RMA (Fig. 2), and national guidance on coastal hazards and climate change (Fig. 2) [39]. The orientation of the NZCPS is precautionary, and it requires councils to have a planning horizon of at least 100 years. The requirement to avoid increasing risks due to natural hazards and climate change (Objective 5) is elaborated in Policies 24-27 (Fig. 3), which include locating new developments (including infrastructure) away from areas prone to coastal hazards, consideration of managed retreat for existing developments exposed to hazard risk, and restoring natural defences against coastal hazards. Direction to avoid increasing risk of harm from coastal hazards includes: encouraging land use changes or redevelopments that reduce risk of adverse effects from coastal hazards; and discouraging hard protection structures because they interfere with dynamic physical processes, public amenity values and can result in increased erosion of adjacent sections of the coast, and promoting alternatives, including natural defences.

Implementation of land-use planning provisions, emergency management and the provision of basic services, are devolved to local authorities comprising regional and local (district and city) councils. The avoidance, reduction and mitigation of natural hazards and disaster risk is regulated through policies, plans and rules at both regional and local council levels, through Regional Policy Statements (together with Regional Coastal Plans) and District Plans. Regional councils predominantly manage coastal erosion and flooding, and water quality and quantity. Local councils manage, among other things, land use planning, building control, emergency management, storm water, wastewater and water supply, and large networks of infrastructure, and local roads. Regional and local councils also use non-statutory planning instruments, including Asset Management Plans and Hazard Mitigation Plans. Statutory requirements for iwi ${ }^{5}$, stakeholder and community consultation guide how community engagement is undertaken.

As both private and public coastal property around Aotearoa-New Zealand is increasingly impacted by coastal hazards compounded by sea-level rise (Lawrence, Bell, Blackett, Stephens, \& Allan, 2018), communities often call for protective measures to prevent impacts on coastal investments. This response runs counter to the statutory direction to avoid and reduce risk by taking a longterm perspective (i.e., 100 plus years) that is not reliant on protective measures. Moreover, it can create a false sense of security and lead to the "levee effect" (Tobin, 1995, p. 365) by exposing communities to greater risk over time and resulting in legacy effects as coastal hazard risks escalate with rising sea levels.

\section{Regional settings}

The Hawke's Bay and Coromandel regions are two national 'hotspots' exposed to coastal change due to development intensification and climate-influenced coastal hazards. Both regions regularly experience coastal erosion and flooding, and both have low-lying communities that are exposed to sea-level rise. Furthermore, both regions have long-standing contestation related to demands to protect valuable at-risk private property investments and critical infrastructure (e.g. coastal roads) with seemingly irreconcilable views and expectations about how to adapt and secure public safety and coastal sustainability (Komar, 2010; Schneider et al., 2017). The proximity of the Coromandel to the main centres of Auckland, Hamilton and Tauranga, coupled with the region's outstanding scenic beauty are key attractions for absentee property ownership which has contributed to rapidly increasing property values. This effect has had less influence in the low-lying areas of Hawke's Bay. For both regions, however, power differentials exist between Māori, local and central government, local communities, and those holding political and economic power, the mediation of which is central to achieving equitable public outcomes (Barrett, Kurian, Simmonds, \& Cretney, 2019; Le Heron et al., 2019; Sunde et al., 2018). These features are commonplace in coastal settings around Aotearoa-New Zealand. Notwithstanding differences in socio-economic enclaves, distinctive local histories and environmental characteristics, coastal communities in both regions share many common institutional, socio-economic, and cultural features.

\subsection{Hawke's Bay}

The Hawke's Bay region, located in the east of the North Island (Fig. 1) comprises varied coastal landscapes, including high cliffs, sand and gravel beaches, coastal lagoons and estuaries. The coastal area examined in this manuscript, from Clifton to Tangoio, comprises coastal communities, including Maori settlements, small holiday and recreational communities, permanent homes and commercial activities. Traditionally, the coast represented key transport routes for hapu as well as a source of food and resources that

\footnotetext{
${ }^{4}$ Tangata Whenua are the Māori people, the original inhabitants of New Zealand, who signed the Treaty of Waitangi / Tiriti o Waitangi (New Zealand's founding document) in 1840, between about 500 Māori chiefs and representatives of the British Crown. The Treaty of Waitangi / te Tiriti o Waitangi guide the relationship between Māori and the Crown.

${ }^{5}$ People, nation, extended kinship group or tribe of Aotearoa-New Zealand's indigenous Māori peoples.
} 


\section{A timeline of key events, publications and policy actions}

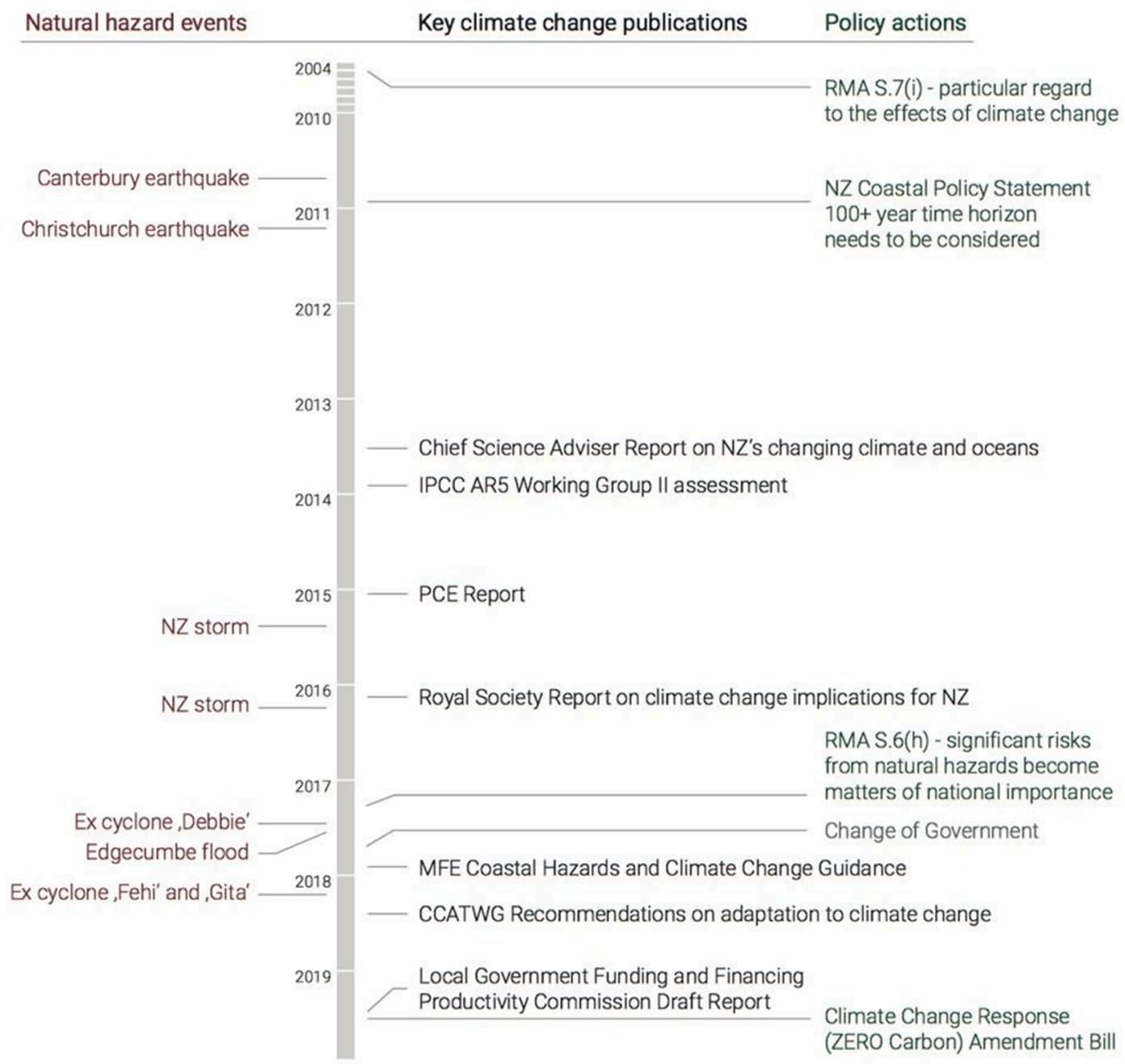

Fig. 2. Key factors shaping risk over the past decade. RMA = Resource Management Act, IPCC = Intergovernmental Panel on Climate Change, PCE $=$ Parliamentary Commissioner for the Environment, MFE = Ministry for the Environment and CCATWG = Climate Change Adaptation Technical Working Group.

remain of great value to Maori (Ropiha, 2017). Customary rights now have legal protection. Napier City, with a population of 62,800 (Statistics New Zealand, 2018), was entirely rebuilt following the M7.8 earthquake in 1931, which resulted in changed land elevations at and behind coastal areas (Komar \& Harris, 2014). Coastal communities have diverse income and asset characteristics, while the hinterland provides a range of regional economic activities that contribute to the rating (property taxes) base of the region, from which council functions are funded.

Adaptation action takes place within the regional and local context and coastal hazard experience. The way climate change and risk are represented in the media spotlights where and how regions are adapting. In the Hawke's Bay, over the past decade, consideration of coastal hazard risk and climate change has gained momentum. This is demonstrated by the rise in the frequency of newspaper articles reporting on the topic (Fig. 4). Articles covering the 'bigger picture - long term' climate change problem, are outnumbered by articles focussing on short-term costs and impact on the ground. In our search we found no adaptation articles relevant to this study were published between 2010 and 2013. Eight articles related to climate change and/or coastal hazard risk in the Hawke's Bay region, were published in 2019.

Coastal erosion has been an issue in parts of the Hawke's Bay region (e.g. Haumoana and Westshore) for many decades and has consequently shaped perceptions of coastal risk in the region. Coastal inundation during storm events and sea-level rise are a growing 


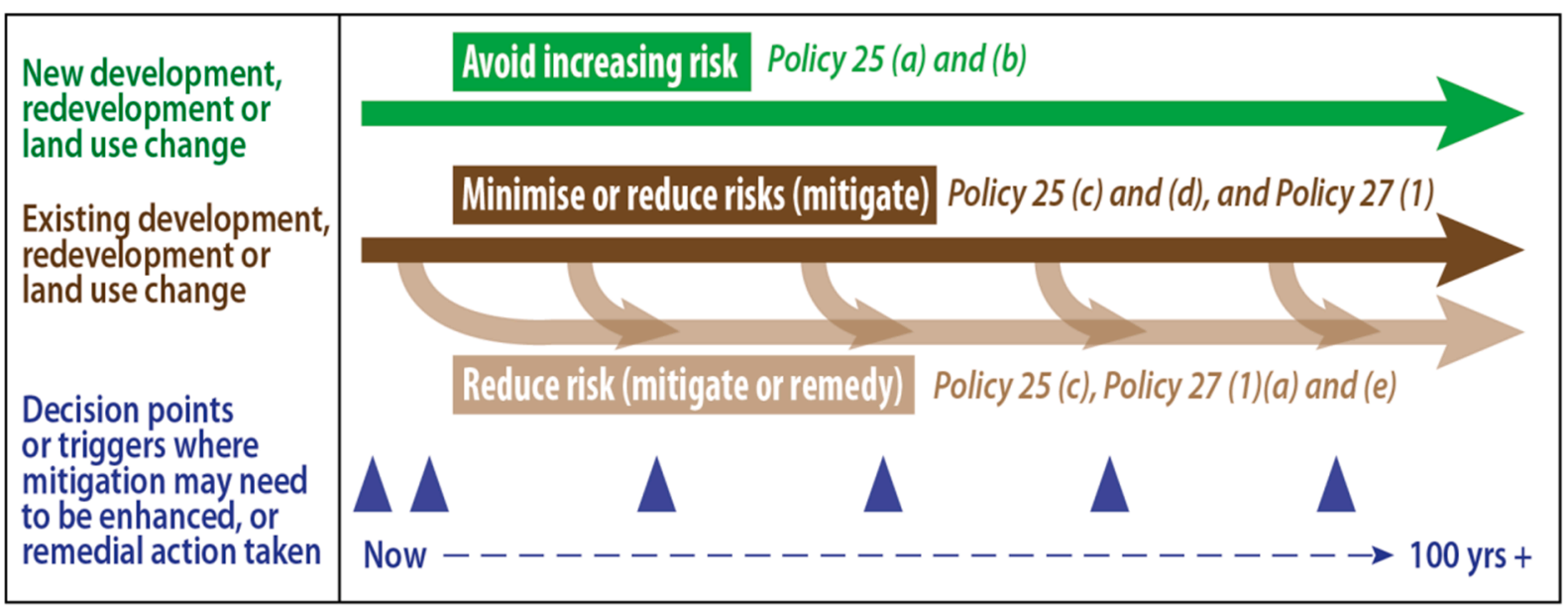

Fig. 3. New Zealand Coastal Policy Statement 2010 decision context for coastal areas exposed to coastal hazards and climate change. Note: uses terminology from RMA 1991 s 5(2) (c) ().

Source: MFE, 2017

concern. As a result, some dwellings have been abandoned (e.g. at Haumoana). There is a long history of scientific investigation about coastal hazards in Hawke's Bay (Komar \& Harris, 2014). The Hawke's Bay Regional Coastal Environment Plan ${ }^{6}$, operative since 2014, applies land use restrictions within coastal hazard zones. Hard coastal structures and beach re-nourishment have, however, typically been used by residents and councils to reduce the impacts of coastal erosion.

Recent demands for protection from coastal impacts using hard structures and beach nourishment (Stancu, 2017), and intensifying publicity about coastal hazards and sea-level rise (Fig. 4 \& supplementary material), led to the three coastal councils in Hawke's Bay Napier City Council, Hastings District Council and the Hawke's Bay Regional Council - setting up a Joint Committee with representatives from three local mana whenua ${ }^{7}$ groups to develop the Clifton to Tangoio Coastal Hazards Strategy 2120 (Strategy). This collaborative approach stemmed from experience with several other challenging public decision-making processes undertaken in Hawke's Bay: to implement New Zealand's National Policy Statement for Freshwater Management regionally; on coastal groynes; an urban development strategy; and a regional transport strategy. Delaying region-wide adaptation action was no longer considered appropriate; working together offered more promise than unilateral efforts by individual councils and other organizations.

The Strategy was initiated in 2014 and developed in four stages (define the problem; framework for decisions; develop responses; respond). It assessed the coastal hazards and risk over the period 2014-2120; developed a decision-making framework to identify, evaluate, consult on and select practicable adaptation options, which could be implemented in a coordinated manner for resilient outcomes across the Hawke's Bay region. This process was supported by two community panels and a collaborative Joint Committee governance arrangement (Corbett \& Bendall, 2019).

\subsection{Coromandel}

The Coromandel region (Fig. 1) is located on the North Island, to the east of Auckland, Aotearoa-New Zealand's largest city. The region comprises a varied coastal landscape, including estuaries, sand beaches and rocky headlands. The communities comprise permanent residents, those on holiday and Māori communities. The over 50 settlements each have their own distinctive personality, history and lifestyle characteristics (TCDC, 2016). Over the summer period (December to March), the area is transformed by an influx of holidaymakers. Larger communities, like Whitianga, have evolved from quiet coastal villages to resort towns over the last 50 years with the population increasing by $600 \%$ in summer. Whitianga's resident population of 4,368 in 2013 (Statistics New Zealand, 2013) is projected to reach a permanent population of up to 6,000 by 2040 , located mainly on low-lying coastal land (Monin, 2012), which is experiencing coastal squeeze and faces escalating coastal hazard risk. Seventy percent of the Coromandel region's beach areas and dunes are developed within $100 \mathrm{~m}$ of the sea (ARC, 2004), in areas identified to be at risk from coastal hazards (TCDC, 2015). The legacy of historical development decisions, ongoing development pressures, high increases in property values, and the development of new coastal areas (greenfield development), have hindered long-term proactive adaptation action in this region (Schneider et al., 2017).

Fig. 5 portrays the level of attention focused on climate change and coastal hazard risk in the Coromandel region. Unlike in Hawke's Bay, the 'bigger picture - long term' climate change articles outnumber those focusing on costs and impacts on the ground. No relevant articles were published between 2010 and 2012, while eight articles related to climate change and/or coastal hazard risk were

\footnotetext{
${ }^{6}$ Available at: https://www.hbrc.govt.nz/documents-and-forms/rcep/

7 Mana whenua groups hold indigenous customary authority over the local land.
} 


\section{Newspaper articles: Hawke's Bay \\ Cost/impact - short term \\ Bigger picture - long term}

No relevant articles related directly to coastal risk / climate change between 2010 and 2013

Halt Hawke's Bay gravel extraction - US expert

2013

Smaller groyne seen as answer to Haumoana worries

2014

Climate change wake-up call

2015

Where the rising seas will hit Kiwi homes

Large part of Napier are vulnerable to sea level rise

Coast damage from climate change to continue

2016

No relevant articles related directly to coastal risk / climate change in 2016

Council plans to fight rising sea levels

Cost of tackling coastal inundation

Counting the cost of sea level rise

Insurers warn climate change will hit policy prices How climate change could send your insurance cost soaring

Here's why your insurance might go up

Nzers pay a premium for true waterfront despite threat

Climate change costs are hitting households

Kiwis held ransom with climate change outlook

Council's $\$ 8 \mathrm{~b}$ climate change warning

$\$ 30 \mathrm{p} / \mathrm{a}$ for defences against coastal erosion

Climate change forces disabled community to move
2017

NZ had its hottest ever recorded year in 2016 Government lacks 'coordinated plan for climate change

2018

Leading academic wants climate change debate

NZ council leading the way

2019

Coastal areas need more support from Government Rising seas could result in relocation plans within a decade

National climate change framework needed

Fig. 4. Newspaper articles reflecting a shift in momentum in risk perceptions in the Hawke's Bay.

published in 2019.

Historically, there has been strong reliance on structural protection for at-risk infrastructure assets and properties (Schneider et al., 2017). A major storm event in January 2018 caused devastation along large stretches of the coast of the Coromandel. Schneider \& Glavovic (2019) suggest that this storm could be a catalyst to rethink the long-term viability of this approach. The Thames-Coromandel District Council (TCDC) currently addresses adaptation through its 2018-2028 Long Term Plan (LTP ${ }^{8}$ ), in which it assesses major infrastructure decisions against coastal hazards and climate change guidance by government at the national level (MFE, 2017). Implemented as part of the LTP, TCDC aims to improve coastal planning and address risks associated with erosion through its 2018 Coastal Management Strategy, which includes the development of Shoreline Management Plans as "part of the focus on ensuring our communities are engaged, prepared, protected and safe in the long-term" (TCDC, 2019a, para. 17). Fragmented planning, however, remains commonplace for the time being, evidenced by the recent consenting of low-lying coastal developments, for example, an upgrade of exposed Whitianga Town Centre completed in 2019, an elder care facility "deemed a flood risk" (Biddle, 2019) on low-lying land in Thames, and the ongoing armouring of the Coast Road north of Thames following storm damage in January 2018.

${ }^{8}$ https://www.tcdc.govt.nz/Your-Council/Documents-incl-Bylaws-Policies-and-Strategies/Long-Term-Plans/Long-Term-Plan-2018-2028/ 


\section{Newspaper articles: Coromandel \\ Cost/impact - short term \\ Bigger picture - long term}

No relevant articles related directly to coastal risk/ climate change between 2010 and 2012

2013

The hidden cost of seaside living in the Coromandel

Councils put up united front against erosion

2015

Residents flee from water's edge as coastal erosion sets in

Coastal inundation tool will warn of risks for seaside properties

2016

No relevant articles related directly to coastal risk / climate change in 2016

Billions at stake as Government mulls sea level rules

2017 in review: A year of storms, slips, fires, rescues, murals and myrtle rust

Insurance council to give talk in Thames Coromandel businesses face losses after storm damage Storm surge's wall of water one of the biggest recorded Does the taxpayer fund climate compensation?

Peninsula Problems: A small council fights a rising sea Retirement Villa deemed flood risk by council vote against climate change declaration
2017

Low-lying Waikato towns at risk from sea-level rise

Climate scientist James Renwick to speak in Thames

Government lacks 'coordinated plan' for climate change

2018

A summer of weather extremes could be the new normal

Thames-Coromandel: The elderly hub of NZ

2019
Long-term thinking needed on climate change

Signing declaration won't stop climate change

Fight against climate complacency

Councils may soon be liable for climate change

Extreme waves are getting higher

Students demand climate change action

Council taken to court over climate declaration decision

Fig. 5. Newspaper articles reflecting a shift in momentum in risk perceptions on the Coromandel.

\section{Key themes depicting adaptation in both regions}

Thematic analysis of key informant interviews revealed four themes that shed light on comparative adaptation experiences and prospects in both regions: understanding and perceptions of coastal hazard risk, trust and legitimacy, community engagement, and governance (Table 1). The results are presented using these themes and are the basis for this comparative analysis. These findings are then discussed in the context of the four issues that emerged in the review of adaptation barriers and enablers literature in section 2. The two sets of interviews (2016 and 2018) undertaken in Hawke's Bay illustrate how the community panel intervention and the multilevel governance arrangement supporting the Strategy development influenced the adaptation options recommended and the planning based on the Strategy. We reveal a shift in perceptions and levels of trust that developed over the course of the Strategy development, which is also illustrated by the media coverage of coastal issues and adaptation over time (Figs. 4 \& 5). Table 2.

\subsection{Hawke's Bay findings}

\subsubsection{Understanding and perceptions of coastal hazard risk}

The 2016 interviews showed that coastal hazard risk was predominantly framed in the immediate-term: "for the foreseeable future we need security" (elected councillor \# H-1) and perceived chiefly as coastal erosion (Table 1). However, the wider community and council interviewees in the 2018 interviews recognized that risk is ongoing and requires long-term options to address the combined 
Table 1

Thematic Analysis: Hawke's Bay and Coromandel regions.

\begin{tabular}{|c|c|c|c|}
\hline Themes & Hawke's Bay & Hawke's Bay & Coromandel \\
\hline & 2016 & 2018 & 2018 \\
\hline $\begin{array}{l}\text { Understanding and } \\
\text { perceptions of } \\
\text { coastal hazard } \\
\text { risk }\end{array}$ & $\begin{array}{l}\text { Different levels of understanding Problem } \\
\text { framed as coastal erosion Low } \\
\text { understanding of sea-level rise and } \\
\text { compound flooding hazards Impacts at the } \\
\text { coast perceived as a local community issue } \\
\text { Focus on at-risk houses and road Social } \\
\text { values partially considered High } \\
\text { confidence in structural protection } \\
\text { measures }\end{array}$ & $\begin{array}{l}\text { More congruent levels of understanding } \\
\text { Perception of problem as coastal erosion } \\
\text { and ongoing flooding Improved } \\
\text { understanding of sea-level rise and } \\
\text { compound flooding hazards Perceptions } \\
\text { shifted to also include region-wide issues } \\
\text { Some non-asset values considered, } \\
\text { including cultural and ecological values } \\
\text { Retreat options considered for the long- } \\
\text { term, but structural measures dominated } \\
\text { short-term options }\end{array}$ & $\begin{array}{l}\text { Different levels of understanding Problem } \\
\text { framed as coastal erosion Low } \\
\text { understanding of difference between } \\
\text { climate change mitigation and adaptation } \\
\text { Impacts at the coast perceived as } \\
\text { manageable and high confidence in } \\
\text { structural protection Focus on at-risk } \\
\text { structural assets Social values not given } \\
\text { due weight Low understanding that } \\
\text { structural protection negatively affects } \\
\text { public amenity values or ecosystems A } \\
\text { "no-worries" mindset alongside reactive, } \\
\text { wait-and-see" attitude }\end{array}$ \\
\hline Trust and legitimacy & $\begin{array}{l}\text { Low trust in Councils Media focus on } \\
\text { climate change controversies Desire for } \\
\text { decision processes to be transparent Initial } \\
\text { scepticism about whether the Strategy } \\
\text { process would work }\end{array}$ & $\begin{array}{l}\text { Trust growing Strategy process was } \\
\text { transparent Strategy process well regarded } \\
\text { and judged legitimate }\end{array}$ & $\begin{array}{l}\text { Low trust in the local council Doubt that } \\
\text { local council will enable adaptation } \\
\text { National coordinating mechanisms for } \\
\text { planning and funding expected to bring } \\
\text { greater consistency of adaptation actions } \\
\text { nationally, while enabling locally relevant } \\
\text { responses }\end{array}$ \\
\hline $\begin{array}{l}\text { Community } \\
\text { engagement }\end{array}$ & $\begin{array}{l}\text { Some felt key values were not fully } \\
\text { acknowledged e.g. Māori values and } \\
\text { coastal amenity values Community } \\
\text { welcomed the Strategy process }\end{array}$ & $\begin{array}{l}\text { Community values were weighted in } \\
\text { decision process Some mana whenua } \\
\text { representatives felt further weighting of } \\
\text { their values was needed Community } \\
\text { lauded the collaborative Strategy process }\end{array}$ & $\begin{array}{l}\text { Local council does not engage enough with } \\
\text { communities who are neither informed } \\
\text { about climate change nor involved in } \\
\text { adaptation planning Many resist } \\
\text { engagement wanting to make the most of } \\
\text { the "here and the now", while parts of the } \\
\text { community recognise that long-term } \\
\text { thinking via engagement is critical }\end{array}$ \\
\hline Governance & $\begin{array}{l}\text { Political leadership established a region- } \\
\text { wide co-operative governance } \\
\text { arrangement, with regional and local } \\
\text { councils and mana whenua } \\
\text { representatives }\end{array}$ & $\begin{array}{l}\text { Governing authorities involve community } \\
\text { representatives and key stakeholders } \\
\text { through Community panels and Joint } \\
\text { Committee that are pivotal to Strategy } \\
\text { completion }\end{array}$ & $\begin{array}{l}\text { Governance arrangements inhibited by } \\
\text { weak local-regional council interactions, } \\
\text { and insufficient community concern about } \\
\text { climate change or the political will to } \\
\text { mobilise action }\end{array}$ \\
\hline
\end{tabular}

Table 2

Overview of the prevailing adaptation situations at the time of the interviews in the Hawke's Bay and the Coromandel regions.

\begin{tabular}{|c|c|c|}
\hline Themes & Hawke’s Bay (2016-2018) & Coromandel (Pre-2018-post-2018) \\
\hline $\begin{array}{l}\text { Understanding and } \\
\text { perceptions of coastal } \\
\text { hazard risk }\end{array}$ & $\begin{array}{l}\text { Shift from differences in understanding and preoccupation with } \\
\text { protective measures to bigger plan thinking and perceived } \\
\text { credibility, salience and legitimacy of information provided. }\end{array}$ & $\begin{array}{l}\text { Perception that coastal assets can be protected, and climate } \\
\text { change is a future problem. Climate risk downplayed. A static } \\
\text { perception of and reaction to the dynamic nature of coastal } \\
\text { hazards and climate change is discernible. The storm event in } \\
\text { January } 2018 \text { was perceived as a 'game changer'. The } 2019 \\
\text { development of the Coastal Management Strategy signals } \\
\text { attention to longer-term adaptation planning and disaster } \\
\text { risk reduction. }\end{array}$ \\
\hline Trust and legitimacy & $\begin{array}{l}\text { Trust has been built over the time of the community panel } \\
\text { process which has contributed to the perceived legitimacy of the } \\
\text { Strategy process and recommendations. }\end{array}$ & $\begin{array}{l}\text { Trust appears to be lacking, dissonance prevails and ad-hoc } \\
\text { protective measures carried out with minimal community } \\
\text { involvement. Development of the Coastal Management } \\
\text { Strategy signals a shift to overcome these barriers. }\end{array}$ \\
\hline Community engagement & $\begin{array}{l}\text { The Strategy development process opened up new opportunities } \\
\text { for community engagement to build shared understanding and } \\
\text { reach agreement on long-term adaptation actions. }\end{array}$ & $\begin{array}{l}\text { Historically, community engagement on coastal hazard risk } \\
\text { issues has been perceived as ineffective. The Coastal } \\
\text { Management Strategy reflects a change in the status quo and } \\
\text { identifies community engagement as being central to } \\
\text { planning and decision-making for the future. }\end{array}$ \\
\hline Governance & $\begin{array}{l}\text { The Strategy development process brought together governance } \\
\text { actors within and between local authorities, iwi, key } \\
\text { stakeholders and the public, with the aim of addressing } \\
\text { adaptation barriers evident from historical dysfunctional } \\
\text { governance arrangements and processes. }\end{array}$ & $\begin{array}{l}\text { The January } 2018 \text { storm event was a focusing event that } \\
\text { spotlighted the need to address adaptation barriers arising } \\
\text { from impaired governance practices and limited community } \\
\text { and political will to address coastal hazard risks in a changing } \\
\text { climate. The Coastal Management Strategy opens up } \\
\text { potential for proactive, collaborative and long-term } \\
\text { adaptation planning. }\end{array}$ \\
\hline
\end{tabular}


effects of coastal erosion, sea-level rise and increased storminess: "At some point we are going to have to face the dangers at the coast" (elected councillor \# H-2). Adaptation options discussed by the immediately affected interviewees were predominantly structural protection options to address the immediate and visible erosion impacts on roads and property, and such options were considered a feasible long-term solution. The impact of ongoing sea-level rise on groundwater flooding in low-lying areas, and the complex interaction between coastal processes, were not fully understood or were discounted by those directly affected at the coast and further inland at low-lying facilities (e.g. the airport). These complexities appeared to be understood by council interviewees, who acknowledged that "human beings sort of innately discount uncertainty and also discount futures" and "there is that kind of discounting of futures and an inclination to expect incremental change" (council manager \# H-3).

The 2016 interviews identified that coastal hazard risks were perceived as having serious public implications for the region. A plan was needed to address the issues facing those immediately at risk from erosion and flooding, those who may need to move away from the hazard, and ratepayers who will be expected to contribute funding for the actions (Table 1).

The 2018 interviews showed palpable tension between those affected and the wider community relating to: issues of place, individual property rights and responsibility, and fairness and equity (Table 1). One interviewee summed this up: "We've got this tension between personal, private investments, public investments versus environmental well-being" (community member \# $\mathrm{H}-4$ ).

These interviews revealed the need for simple, clear information to build understanding about coastal hazard risks, acknowledging that this will take time. Community interviewees also called for options that could obtain wide ratepayer support, rather than "quick fixes of a temporary nature" (community member \# H-5).

\subsubsection{Trust and legitimacy}

The 2016 interviews showed that all interviewees were pleased that the collaborative Strategy was being developed to address long-standing coastal hazard issues. They were cautiously optimistic that the Strategy process proposed would be successful but were sceptical that a tangible outcome would result (Table 1). The scepticism was related to: 1) the history of a longstanding coastal management problem in Hawke's Bay, punctuated by many reports and little perceived action on the ground, despite some temporary protection and maintenance actions; 2) each council could still make independent decisions that could potentially undermine the collaborative exploration of region-wide options and long-term solutions, for example, consent applications for groynes and sea walls were in the planning system as the Strategy development started; and 3) whether local community pressures would 'champion' expensive structural protection requiring regional acceptance and funding. These three factors reflected a low level of trust in councils to advance decision-making toward a 'solution' that the whole region would agree to (Table 1). The media was viewed by some as focusing on controversy, which was considered to have previously undermined council's efforts in coastal adaptation.

The 2018 interviews showed that the Strategy engagement process had generated a significant shift in trust in councils (Table 1) and "I think it's been a game changer", “ we're actually now getting the sense that maybe through this process ... there's a greater willingness to work together" [\# H-6]. Community panel members lauded the councils for opening up the space for their concerns to be aired over the two year-long engagement process. For example, one enabler identified was how the Chair of the Joint Committee made space at the beginning of each panel session for community concerns to be raised. This helped legitimize the process and outcome, which could then be accepted for advancement to the next stage in the adaptation planning decision-making process by the three councils.

While mana whenua representation on the community panel process was viewed positively, the 2018 interviews highlighted that further work is required to gain iwi trust and legitimacy at the implementation stage (Table 1). Building better understanding of others' values was viewed as essential for getting acceptance across the wider Hawke's Bay community to enable implementation of the Strategy.

Three actions were taken by councils during the Strategy process that were seen by some as undermining trust and potentially compromising the legitimacy of the Strategy. These actions were: 1) different building codes being applied by the two district councils regarding foundations (concrete slabs vs raised floor levels respectively); 2) a rock wall resource consent was approved in a high-risk area; and 3) a master plan for the estuarine area was being prepared in parallel but not linked to the Strategy. However, others considered that these actions demonstrated councils' willingness to take action to protect local community assets and interests in parallel with region-wide adaptation planning.

\subsubsection{Community engagement}

The 2016 interviews identified the need for community engagement that could reach a long-term risk reduction outcome and lead to better understanding between those affected on the coast and the wider regional community (Table 1). Interviewees with a regional focus and those directly at-risk wanted to see the coastal hazard risk issue reframed from a problem that experts identify, to a wider community issue that could gain acceptance from those affected and the wider community who may have to pay for interventions over the long term. For example, many of the 2016 interviewees wanted engagement with the insurance sector, emergency and utility services, business community, and with central government about the wider flow-on effects of the Strategy nationally.

The 2018 interviews highlighted councils' limited understanding of Māori culture and its relevance to addressing coastal issues (Table 1). A particular concern to iwi, was their view that councils had an expectation that iwi would address their own issues, rather than exercise collective responsibility in addressing them. The 2018 interviews indicated that the Strategy process had started with definite views amongst the community panel members about the outcomes they wanted. There were perceptions that the councils came to the table with predetermined views and that consultation was only undertaken to support their preference for managed retreat. Nevertheless, the Strategy process had enabled some wider engagement of business interests (Table 1) through representation on the community panels. When asked what lessons could be passed on to others from the community engagement process used in 
Hawke's Bay, a community member (community member \# H-6) stated: "consult, talk with people, become informed before making decisions so there's a process of learning that's required to understand long term impacts".

\subsubsection{Governance}

The 2016 interviews showed that all parties were relieved that a coordinated approach by the three councils and mana whenua groups had begun and could enable long-term outcomes to be agreed upon (Table 1). It was recognized that councils had been unable to agree on coastal management approaches over many decades: "I was probably quite sceptical to start with because we'd seen multiple processes with councils over multiple years and they collapsed in the end" (community member \# H-6). Interviewees hoped that the Strategy process could break the impasse and re-frame the coastal hazard issue as a region-wide one and for it to be given due priority. Enabling a decision process led by a clear and effective governance framework (the collaborative Joint Committee together with meaningful community engagement) and a prescribed decision framework was viewed as very positive.

The 2018 interviews indicated surprise that recommendations had been agreed upon and endorsed in principle by all partner councils for development of the implementation phase. As one interviewee put it: "it's quite miraculous that such a group of people actually did end up with recommendations" (community member \# H-7).

Concern about the ability to pay for appropriate responses to changing coastal risk featured highly in most of the 2018 interviews, for example: "after 30 years I think there's going to be lots and lots of challenges for people along the coast, which won't be solved by hard engineering" that "is going to cost a bomb of money" (community member \# H-7). The 'ability to pay' was characterized as the crucial governance issue going forward (Table 1). There was much scepticism amongst interviewees about whether funding for implementing the recommendations would be available, and whether or not the expenditure would be challenged by the wider community at the implementation stage. One interviewee commented: "the implementation phase is the hard part because that's where you start spending the dosh. And you've got to have these really difficult discussions around how do you split [the costs] between regional and district councils and how do you split between the coastal communities and the public good and those further back [inland]. They are the really hard conversations" (elected councillor \# H-2).

Having a funding mechanism in place and the willingness of the wider community to support investment, was seen as crucial for implementing the proposed adaptation actions (Table 1). Delivering on such governance supporting provisions and mechanisms was considered the ultimate test of the level of trust built during the Strategy process, and thus ultimately would determine the legitimacy of the Strategy outcomes.

\subsection{Coromandel findings}

The insights provided by Coromandel interviewees were strongly influenced by the 5th of January 2018 storm (return period of $0.5 \%$ ) - an extreme event for the region that was uppermost in people's minds at the time of the interviews. Increased media coverage of coastal hazard risk and climate change-related topics compared to the past (see Fig. 5) also played a part in interviewees' awareness. The January 2018 storm destroyed much of the Thames Coast Road, the only road connecting the communities on the Peninsula's west coast, as well as damaging many coastal properties. Research participants perceived the storm to be a "game changer" for addressing barriers to coastal adaptation; as a window of opportunity for prioritizing risk reduction and breaking the cycle of continually repairing assets in locations exposed to repeated damage.

\subsubsection{Understanding and perceptions of climate change}

The Coromandel has experienced "major erosion along several areas of our coastline" (TCDC, 2014, para. 2) for decades and this has been addressed by the local authority through statutory building restrictions and coastal setback zones. However, ongoing development along the shoreline has been approved in some places, and many beachfront property owners have used rocks and ad-hoc structures to protect their properties. A perception prevailed amongst many influential stakeholders interviewed that climate change is not a problem for the region. Understanding about the reality of climate change and what it means for coastal communities varied but was generally low (Table 1). Those in local authority agencies professionally engaged with climate change and adaptation issues were generally well informed and aware of the challenges in preparing coastal communities for changing coastal conditions: "We are clearly getting a change in the risk profile with climate change" (regional council staff member \# C-1). Many interviewees, however, did not understand the distinction between climate change mitigation and adaptation. Many interviewees thought that coastal hazard risk is limited to erosion and is a short-term issue that can be 'fixed' by installation of hard protection structures. There was little consideration of the implications of ongoing sea-level rise, and limited understanding about its consequences or how it is already contributing to coastal impacts (Table 1). Many interviewees held the view that: "erosion is probably the biggest risk" (elected councillor \# C-1) rendering the problem technical and manageable. Erosion is visible to all and routinely addressed by hardening the shoreline with rocks: "There's rocks all along and there'll eventually have to be rocks right along the whole beach to protect the town" (elected councillor \# C-2).

The interviews revealed that the storm was a focusing event (Birkland, 2016a): "In a perverse sort of way, it was quite good", a community member (\# C-1) remarked. Before January 5, 2018, there was a "no worries"9 wait-and-see mindset about coastal hazard risk. Coastal development was seen as progressive and desirable. However, this view was challenged by observing how quickly a storm

${ }^{9}$ Colloquial term used in New Zealand and Australia to express optimism about the outcome of a situation. 
can devastate low-lying and beachfront settlements. Interviewees did not link the storm to climate change. They perceive coastal risk to be part of the reality of coastal living. They think that it will take more than one such destructive event "before funds really get applied [...] like a repetition of the January 5 [2018] storm and so on" (elected councillor \# C-4). There are divergent perceptions of climate change and coastal hazard risks, and different levels of understanding. A widely held view prevails that protective measures are the most appropriate response to coastal hazard risk. Some regional council and community interviewees were, however, very aware of the implications of climate change, and the need for longer-term adaptation approaches that could be enabled by local council leadership.

\subsubsection{Trust and legitimacy}

Some interviewees have low levels of trust or confidence in the local council's approach to climate change adaptation (beyond protective responses) (Table 1), due to perceived inaction to date and ongoing consenting of coastal development in exposed localities. Low levels of trust and concerns about legitimacy were driven at least in part by council leadership questioning the contribution of climate change to coastal hazard risk: "Basically council can ignore all guidelines and all provisions that have some sort of say about hazards and climate change. They can basically turn a blind eye [...] and no one's going to pull them up on it. The whole process isn't working. If they want to, they'll find some way to scoot around the provisions and say they, oh well, they don't apply to us" (community member \# C-1).

There was also praise from some interviewees that the local council is "doing what needs to be done" by protecting coastal communities from further erosion. "For me, council has a responsibility specific to what it's tasked to do - and part of that is to protect the coast [from erosion]. Understanding what we are doing going forward to address these issues is important" (regional council staff \# C-2). Trust in the council was fostered when the local Mayor publicly praised the protective measures being taken by the national roading agency following the January 2018 storm event, because actions demanded by the public were being taken.

\subsubsection{Community engagement}

The interviews highlighted the challenge of engaging the community in ways that reconcile immediate needs and address current pressures as well as the long-term implications of climate change (Table 1). Interviewees generally did not make the connection between coastal hazard risk prospects in a changing climate and coastal development trajectories, including council decisions to grant consents for substantial new development on low-lying coastal land, and personal decisions, such as investing in at-risk beachfront property. Some interviewees reported a "reactive" mindset to climate change (Table 1), with communities left "in the dark" about ongoing sea-level rise and the options available to adapt.

Questions arose about how to engage communities in council planning and decision-making. A council staff member (\# C-3) pointed out the need for "[...] using people's strengths and to respect and listen to them - not just always pushing views at them but trying to understand their views. It's not necessarily the organizations or consultants who know best but often the individuals on the ground". Interviewees reported consistently that the January 2018 storm had the potential to be a window of opportunity for meaningful engagement with the community and development of adaptive pathways. Interviewees pointed out that the storm provided visible insights about the exposure and vulnerability of settlements in the Coromandel region. A local council staff member (\# C2) explained the need for a "meaningful discussion" as the "first step" after such an event: "I would call it an open forum day where we wouldn't be coming with answers but actually going into the community. All the agencies involved would contribute the information on what we know to date. Then the community can express their visions and provide input and feedback. The main question will have to be "how can we work together?",

\subsubsection{Governance}

The interviews suggested that governance of coastal hazard risk on the Coromandel has been constrained by limited proactive action on the part of the TCDC as well as a disconnect between the local and regional councils (Table 1). An interviewee emphasized the "need to get TCDC more involved" (regional council staff member \# C-3) in adaptation as a means of bringing the regional and local council together to address climate change. A local council staff member (\# C-2) explained that they "would like to think [the relationship between the councils] to be improving" whereas in the past there was "a lot of us and them sort of thing". A misalignment of planning and decision-making frameworks and interests was seen as the main inhibitor for joint governance arrangements: "We wait for Regional Council to tell us what to do [...] this is not our responsibility. But we can't work like that, we have to work collaboratively on this" (local council staff member \# C-2). The underutilization of statutory planning measures that could avoid further entrenchment of coastal hazard risk was noted and evidenced by ongoing consenting in at-risk areas: "We just carry on sort of pretending there's not a problem" (local council staff member \# C-2).

Interviewees with understanding about coastal hazard risks commented that adaptation is currently reliant upon static and shortterm approaches, such as seawalls and other structural 'protection' measures, which fail to consider the advancing and ongoing risks from climate change across regional and local council mandates. One interviewee from the community (\# C-5) stated that there will be no adaptation progress without local authority leadership and governance practices that can make joined-up long-term decisions: "I just cannot understand why we should not be at the forefront [of adaptation] because Thames is probably one of the most risky settlements in New Zealand". However, interviewees were also clear that regional and local councils require greater national government support for adaptation planning and action; and that coordinating mechanisms for planning and funding would bring greater consistency in adaptation actions nationally, while still addressing distinctive local characteristics and interests. Interviewees said that if national government was to provide stronger leadership and direction, this could become a "key driver" for local government to more effectively manage climate change impacts alongside other hazards. The electoral cycle of three years was seen to inhibit long- 
term leadership and a legislative catalyst for proactive adaptation may be required to "cut through" local politics: "to be brutally honest there is a sort of political ideology behind all this with some people [being guided by] their selfish you know venal interests" (regional council staff member \# C-1).

\section{Reflections on comparative experience in the two regions}

The Hawke's Bay and the Coromandel regions are at different points in their unfolding adaptation journeys. What until very recently appeared to be divergent responses to coastal hazard risk in a changing climate, appears to be shifting. There is a 'rising tide' of adaptation action, in the face of escalating climate change impacts and risks, as historically, fragmented efforts, inaction and reliance on structural protection give way to more joined-up efforts to develop longer-term adaptive responses to climate change. Insights from the interviews show that the process of proactively addressing adaptation barriers began in the Hawke's Bay with the initiation of the Strategy process in 2014. In contrast, at that time, there was no evidence of proactive long-term adaptation action by the TCDC, other than reliance on structural protection; coastal hazard risk was framed as a 'coastal erosion problem' and some local leaders were apparently in denial about the reality of climate change (Schneider et al., 2017). This situation may, however, have changed in only a few years, as signalled by the development of the Coastal Management Strategy, which was initiated in 2018-2019. What sparked this change? And what does the comparative experience in the Hawke's Bay and Coromandel reveal about adaptation barriers and enablers, and the pathways communities and their governing authorities choose deliberately or inadvertently find themselves on in practice? In this section we discuss the findings according to the four themes identified through the interviews in relation to the insights gained from the literature review.

\subsection{Understanding and perceptions of coastal hazard risk}

In the Hawke's Bay region there were initially stark differences in understanding the ongoing and dynamic nature of climate change impacts amongst coastal residents, the council staff, elected councillors and the general public, despite many credible sources of readily available information about coastal hazards and climate change. There was a strong perception amongst community interviewees that "for the foreseeable future we need security" (\# H-6), which played out as the choice of short-term protection options in the Strategy, driven by wanting to "stay and fight" because "no one has got their heads around the problem" (\# H-3). By the end of the Strategy development there was a visible shift in understanding about the long-term consequences of sea-level rise. Even though the pathways developed in the Strategy were predominantly 'protection-oriented' in the short-term, the need to switch to more flexible options in the long-term was recognised. It was the Strategy process itself that enabled this shift in understanding to take place by, for example, involving communities in the assessment process alongside the consultants and researchers, and providing overviews and updates on knowledge about local coastal processes and changing risks over time. As a result, participants realized that "people need to see whatever is done is part of a bigger plan and that ad hoc work is to buy a little time" and "at some point we are going to have to face the dangers at the coast" (\# H-7).

In the Coromandel region, the predominant perception has been that climate change is not a problem, but that protection is needed because of frequent storm events and worsening coastal erosion. Limited understanding about how protection strategies can have a limited lifetime and give a false sense of security thus exposing assets and people to greater risk has been a key barrier to advancing coastal climate change adaptation in the region. For example, both the interviews and the action by TCDC 'on the ground' demonstrate how a complex dynamic coastal process that includes sea-level rise was reduced to a 'static problem'. This led to a short-term focus on protective responses in the aftermath of extreme events. There appears to have been limited understanding about how protective measures can negatively impact other local assets, such as public amenity values and ecosystems, and that they can ultimately fail to protect infrastructure assets as sea-level rises. The shift toward longer term thinking visible in the Hawke's Bay Strategy process became apparent in the Coromandel following the storm event in January 2018. The storm was described by the three councillors interviewed (\# C-1; C-3; C-4) as a 'game changer', or a focusing event according to Birkland (2016a). Councillors interviewed shortly after the storm were adamant that coastal planning could not continue the way it had been carried out in the past. The unprecedented and extreme impact of the event ('one-in-200 year') drew attention to the potential for destructive impacts. Initiating the Coastal Management Strategy in 2018 constitutes a marked departure from previous practice and the underlying understanding and perceptions about coastal hazard risk in a changing climate.

These comparative experiences underscore insights from local and international literature which we reviewed in section 2 . In particular, shared understanding about coastal hazard risks and climate change developed as people began to work together on the long-term Strategy in the Hawke's Bay. Scientific evidence about the impacts of climate change on coastal hazard risk had been accumulating and reflected in key domestic and international documents, increasing media reporting, and evolving guidance for local authorities, as well as a review of the adequacy of local climate change adaptation efforts. (CCATWG, 2018; New Zealand Government, 2019; Reisinger et al., 2014; Royal Society of New Zealand, 2016). These reviews have culminated in a new institutional architecture for adaptation-periodic National Climate Change Risk Assessments, National Adaptation Plans and a Climate Change Commission to monitor progress ${ }^{10}$. Locality-specific information about coastal hazard risk and climate change became more readily available to the public, stakeholders, iwi and government authorities (MFE, 2017; ibid.). As a consequence, and as a result of active involvement,

\footnotetext{
$\overline{10}$ Set out in the Climate Change Response (Zero Carbon) Amendment Act 2019.
} 
participants in the Hawke's Bay Strategy process increasingly viewed the information underpinning the Strategy, and the process itself, to be credible, salient and legitimate (see Cash et al., 2003). Moreover, consistent with Lemos et al. (2012), narrowing the gap between climate information and its usability in the Hawke's Bay is promising because (i) the underlying information and decision tools used 'fit' the problem at hand - escalating coastal hazard risk in a changing climate along the Clifton-Tangoio coastline (Lawrence et al., 2019b); (ii) there is an 'interplay' of climate information and understanding with other knowledges, including local and Māori knowledges - albeit there is room for improvement to better align the Strategy with Mātauranga Māori, (i.e., wisdom); and (iii) positive 'interactions' had been established within and between governing authorities in the region, iwi and hapū (sub-tribe), key stakeholders, researchers, and the general public. It remains to be seen whether the climate change strategy and planning processes recently initiated on the Coromandel Peninsula will lead to similar rapid advances in shared understanding about coastal hazard risk in the region, and shared perception of the need for urgent, coordinated and sustained adaptation action. An insight we draw from this comparative experience that may have wider resonance is the enabling influence of a legitimate process for building shared understanding about coastal hazard risk in a changing climate. The Hawke's Bay Strategy process provided a safe arena for participants to gain ready access to and reflect on a wide range of credible information sources, including input by independent experts across New Zealand and internationally. This access to credible and salient information, coupled with increasing attention in public media, enabled notable improvements in understanding about local risks and adaptation prospects.

\subsection{Trust and legitimacy}

By designing collaborative governance arrangements that were inclusive of regional interests with clear objectives for addressing coastal hazard risk, the Hawke's Bay governing authorities exercised the leadership required to start a community engagement and assessment process. Experience gained from other collaborative planning across councils and engagement with the community, enabled the councils to do likewise in developing the coastal hazards Strategy. This approach enabled trust to be built, which in turn led to legitimacy of the recommendations from the community panels, based on information deemed credible and salient (Cash et al., 2003; Lemos et al., 2012). It also engendered collaborative problem-solving by enabling difficult conversations about coastal decision making to occur in the Strategy development process.

In contrast, overall trust in local government in the Coromandel regarding coastal adaptation was low at the time of the interviews. The interview data and newspaper articles revealed how council's adaptation actions were perceived, highlighting dissonance within the local council, low community engagement in adaptation, ad-hoc protection-oriented reactions to extreme events, and a lack of coordinated adaptation leadership by the TCDC and the regional council. Actions to protect exposed assets continued to be lauded by those seeking immediate relief through council intervention. Building trust to move beyond protective responses may be hindered by the perceived need to protect significant coastal investments at risk in the short-term, due to 30\% of the Thames population being retired and the transient nature of the Coromandel population given its nationally popular holiday destination status (Davison, 2011). Experience in the Hawke's Bay suggests that recent actions by the TCDC to develop a Coastal Management Strategy could help to build community trust in the governing authorities and improve the perceived legitimacy of resultant interventions. For this to happen combining the strengths between the local and the regional council in the Coromandel (RMLA, 2020) and establishing a working relationship with the Hawke's Bay authorities could foster learning and build on the work already started.

Local leaders play a crucial enabling or constraining role in 'opening up' or 'closing down' adaptation opportunities and the pathways taken (Termeer et al., 2017, 2011). The design of adaptation planning or strategy processes is thus crucial, and is key to revealing capability building needs to initiate and sustain adaptation efforts (Lawrence et al., 2015) that foster trust building and legitimacy. Leaders in the Hawke's Bay were instrumental in securing buy-in to the Strategy development process. Will the perceived legitimacy of the Strategy and underlying process be sustained and possibly deepened in Strategy implementation? Questions remain about how trust and legitimacy of the Coastal Management Strategy is unfolding in the Coromandel Peninsula. Experience in the Hawke's Bay suggests that trust in adaptation efforts can be built relatively quickly through process design and practices that are deemed credible, salient and legitimate. But trust also can be eroded quickly by ill-designed processes and / or weak leadership. One key observation that may have wider relevance is that even where trust levels are low, and the perceived legitimacy of governing authorities has long been questioned, mounting climate risk or an extreme event can be a catalyst for local leaders to take action, and work in more collaborative ways, that spark adaptation, and by so doing, recalibrate trust and legitimacy.

\subsection{Community engagement}

The Hawke's Bay Strategy process created a distinctive opportunity for the community to engage with local and regional councils, as well as iwi and key stakeholders, to better understand the nature of coastal hazard risk, and develop and assess options for managing risk through short-, medium- and long-term adaptation actions. This led to better understanding of coastal processes and sea-level rise, and what this means for coastal communities now and over the coming decades. Although the community representation was largely focused on those affected, there were several meetings during the Strategy process to inform the general public. The Strategy development process helped to overcome the pre-conceived views and scepticism of some participants. The Strategy created a 'safe space' to discuss issues that had long been contested and unresolved. Some participants expressed relief that they didn't have to spend time debating whether or not climate change was occurring, because of credible information already shared, which meant they could focus on problem-solving. Engagement with mana whenua representatives in Hawke's Bay achieved through the Joint Committee, the community panels and a cultural assessment engendered learning across the community panels. The barriers to this learning were in part addressed through a cultural advisor who consulted with Maori and in so doing conveyed a powerful narrative that gave weight to 
indigenous knowledge and lived experience (Te Ao Maori) with respect to working with nature, rather than against it, and the longterm view of the changing environment and related practices.

Opportunities for community engagement to address coastal hazard risk on the Coromandel Peninsula were at best limited and considered to be ineffective by most interviewees. Some officials in the TCDC were concerned about 'rocking the boat' and that drawing attention to escalating coastal hazard risk would unsettle communities with predominantly older residents and deter much desired investment in coastal development. A 'wait and see' approach has contributed to delayed adaptation action. Nevertheless, there are sectors of the community and local council staff that recognize the need for long-term adaptation planning. The recently initiated Coastal Management Strategy opens up significant new opportunities for authentic and meaningful engagement of local communities and coastal stakeholders to develop a proactive long-term approach to coastal hazard risk reduction and adaptation. It remains to be seen if and how this will be translated into practice.

Barriers and enablers for community engagement in adaptation are manifest in the divergent experiences of the Hawke's Bay and Coromandel to date. Long-standing scholarship and practice attests to the challenges inherent in crafting effective community engagement processes to address complex and contested public issues (Arnstein, 1969; IAP2, 2018; Reed, 2008), like coastal hazard risk in a changing climate (Berke \& Stevens, 2016; Lawrence et al., 2019b; Serrao-Neumann et al., 2015a). Experience shows that community engagement goals are more likely to be achieved if government and community members agree on participation objectives and co-design the participatory process (IAP2, 2018; Uittenbroek et al., 2019). Meaningful community engagement in the Hawke's Bay Strategy development process was facilitated by two key considerations. Firstly, leaders from all governing authorities and iwi were committed to ensuring community engagement. Secondly, there was flexibility built into the Strategy process through the encouragement of discussion at the beginning of meetings to enable adjustments as new insights and issues arose in the interactions between the councils, researchers, stakeholders and community representatives as the strategy was being developed. Such considerations will likely be key to charting an effective community engagement process in the Coromandel region, building on previous findings in the area and other places in New Zealand (cf. Rouse et al., 2017). More broadly, the lesson from the Aotearoa-New Zealand experience is that proactive and sustained participation of at-risk local stakeholders (through formal and informal processes and with the wider regional public and formal involvement of Indigenous People, are crucial for enabling authentic community engagement.

\subsection{Governance}

The Hawke's Bay Strategy governance arrangement successfully brought together two district councils and the regional council that had not always worked well together historically. This collaboration enabled recommendations from the community panels to be shepherded through individual council decision processes as required under the governing local government legislation. However, even carefully planned and executed governance does not guarantee a barrier-free strategy development and implementation process. In the Hawke's Bay, a few barriers had to be carefully navigated to bring about shared understanding based on common values as part of collective decision-making. Several considerations emerged as key. First, limited understanding about the nature of the problem by the decision-makers became manifest at the decision-making stage, highlighting the need for improved communication with elected councillors during the course of any such process. Second, early engagement with Maori is an essential partnership principle and is key for good governance in Aotearoa-New Zealand under the Treaty of Waitangi / Tiriti o Waitangi. Third, it is important for senior management in councils to be informed of developments in the process as it is occurring to facilitate the advisory process with the decision-makers. Finally, national legislative direction is vital to enable consistency across councils in addressing coastal hazard risk and charting prudent adaptation pathways.

Governance frameworks to support management of coastal hazard risk in the Coromandel have, in the past, been limited by barriers such as climate change denial, limited understanding of coastal hazard risks by local leaders resulting in a lack of leadership in responding to climate change risk, and weak community engagement, which have compounded low levels of trust in local government, as well as poor working relationships between the local and regional councils. However, adaptation has moved onto the TCDC agenda since the January 2018 storm, with the decision by the local council to develop Shoreline Management Plans "through active involvement of all key stakeholders" (TCDC, 2019b, para. 14) as part of a Coastal Management Strategy, which is to be informed by the national coastal hazards and climate change guidelines for local government (MFE, 2017). Now that the focusing event of the storm has passed, can the requisite trust in the local council be secured and sustained through the Coastal Management Strategy process to engage community members, iwi, stakeholders and other government agencies in the complex and contested decisions to be made? Even if the Strategy formulation process can advance to developing adaptation options and pathways as in the Hawke's Bay, how will the reality of implementing adaptation decisions unfold?

In both the Hawke's Bay and Coromandel regions, emerging strategies have still to be institutionalized (Termeer et al., 2016). For example, the multiple scales of governance are still to be navigated to enable more joined-up planning, decision-making and practice (Amundsen et al., 2010; Araos et al., 2017). The politics across different governance levels will continue to influence and compound decisions and planning processes - with dominant values and interests, risk appetites, coupled with leadership styles (Duijnhoven \& Neef, 2016) and unfunded and unclear mandates for adaptation (Boston \& Lawrence, 2018) being germane to the trajectory of adaptation responses. The experiences contrasted here demonstrate that, even when adaptation mandates and funding remain unresolved, the lived experience of an extreme event and/or the manifestation of escalating climate risk at the coast can galvanize collaboration within and between jurisdictions that may be crucial for effective and sustained adaptation action. 


\section{Conclusion}

Our study of these adaptation experiences in the Hawke's Bay coast and Coromandel Peninsula shows that two regions can share many common traits, and face similar coastal hazard risks, but chart different adaptation pathways; and that this can change direction faster than anticipated. Our research sheds light on the factors driving divergent responses that lead to adaptation action in one setting and inaction in a similar setting, even in the face of escalating coastal hazard risk. We conclude that there is a rising tide of adaptation action in the face of escalating climate risk, as sea levels and more severe storms are on the rise - with long-term planning and local action triggered by cumulative hazard experience and extreme events, progressive leadership and governance arrangements, and situational changes that raise media interest and public concern, and turn adaptation at the coast into a priority for local communities and their leaders.

This research builds upon and advances understanding of adaptation barriers and enablers by: (i) better understanding the nature of and interactions between barriers and enablers in practice; (ii) revealing how interactions between levels of governing authority unfold in practice, and how locally relevant responses can be enabled in a coherent manner within and between regions; (iii) comparing experiences in settings that share common features to better understand what drives different adaptation responses over time; and (iv) shedding light on the ways in which hazard experience and extreme events influence perceptions of risk, leadership and subsequent adaptation planning, including how a major storm becomes a focusing event that opens a window of opportunity for adaptation planning and action.

We observe, firstly, that efforts to overcome adaptation barriers do not automatically translate into enablers - they are not simply the flip-side of a coin: barriers in one setting can manifest as enablers in another; and they are interactive and dynamic influences on the trajectory of adaptation, which can shift suddenly. Secondly, interactions within and between governing authorities at the local, regional and national level, especially within formal governance arrangements, dictate adaptation prospects and local action. Thirdly, local authorities, and civic and elected leadership in particular, play a catalytic role in opening up or closing down opportunities for progressive adaptation; and this is a fast-moving reality that can be dramatically influenced by extreme events. Finally, and related to the foregoing, focusing events can be the catalyst for setting in motion planning for long-term adaptation. Rather than waiting for an extreme event or stressor, the implication of this study is that anticipatory measures can strengthen local-regional council and councilcommunity relationships; secure salient and credible information about local coastal hazard risks in a changing climate; build public awareness and understanding even if climate complacency or denial prevails; leverage local media; and explore innovative ways to encourage progressive local adaptation leadership.

While much progress has been made recently in the Hawke's Bay region, following decades of attempts to address coastal hazard risk, the Strategy still requires region-wide community buy-in for it to be implemented and funding mechanisms created. The Coromandel is now progressing adaptation planning and initiating a strategy development process through work on a Coastal Management Strategy and Shoreline Management Plans. The enablers for this rising tide of adaptation action can be traced back to the January 2018 storm; and to greater and more visible national attention to coastal hazard risk and climate change. Adaptation prospects in both regions are rapidly improving as local communities see the visible effects of changing climate and recognise the need to take long-term action. What remains to be seen is whether the observed shift from reactive to proactive adaptation planning will translate into enduring adaptation actions on the ground.

\section{Declaration of Competing Interest}

The authors declare that they have no known competing financial interests or personal relationships that could have appeared to influence the work reported in this paper.

\section{Acknowledgements}

The authors acknowledge with thanks funding from the Aoteaoroa-New Zealand government National Science Challenge: Resilience to Nature's Challenges - Kia manawaroa - Ngā Ākina o Te Ao Tūroa (GNS-RNC005): The Living at the Edge, Coastal, and Resilience Governance projects; and the Aotearoa-New Zealand Earthquake Commission (EQC). The authors thank all research participants for their contributions. Further, we thank Axel Kreuter (Medical University of Innsbruck) for his work on Figs. 2, 4 and 5.

\section{Author contributions}

PS, JL and BG conceived and wrote the paper; PS and JL conducted the interviews and data analysis with input from ER and PB throughout the data collection, analysis and writing of the paper.

\section{References}

Adger, W.N., 2001. Scales of governance and environmental justice for adaptation and mitigation of climate change. J. Int. Dev. 13 (7), 921-931.

Adger, W.N., Dessai, S., Goulden, M., Hulme, M., Lorenzoni, I., Nelson, D.R., Naess, L.O., Wolf, J., Wreford, A., 2009. Are there social limits to adaptation to climate change? Clim. Change 93 (3-4), 335-354.

Alexa. (2019). Top Sites in New Zealand. Retrieved from https://www.alexa.com/topsites/countries/NZ.

Amundsen, Helene, Berglund, Frode, Westskog, Hege, 2010. Overcoming Barriers to Climate Change Adaptation-A Question of Multilevel Governance? Environ. Plann. C Gov. Policy 28 (2), 276-289. 
Araos, Malcolm, Ford, James, Berrang-Ford, Lea, Biesbroek, Robbert, Moser, Sarah, 2017. Climate change adaptation planning for Global South megacities: the case of Dhaka. J. Environ. Policy Plann. 19 (6), 682-696.

ARC, 2004. Hauraki Gulf State of the Environment Report - Coastal Hazards of the Gulf. Retrieved from Auckland: www.arc.govt.nz/.

Arnstein, Sherry R., 1969. A Ladder Of Citizen Participation. J. Am. Insti. Plann. 35 (4), 216-224.

Barnett, J., Evans, L. S., Gross, C., Kiem, A. S., Kingsford, R. T., Palutikof, J. P., . . Smithers, S. G. (2015). From barriers to limits to climate change adaptation: path dependency and the speed of change. Ecology and Society, 20(3). doi:10.5751/ES-07698-200305.

Barrett, Patrick, Kurian, Priya, Simmonds, Naomi, Cretney, Raven, 2019. Community participation in the development of the Ōngātoro/Maketū Estuary project: The socio-ecological dimensions of restoring an interconnected ecosystem. Aquatic Conserv: Mar Freshw Ecosyst 29 (9), $1547-1560$.

Berke, Philip R., Stevens, Mark R., 2016. Land Use Planning for Climate Adaptation: Theory and Practice. J. Plann. Educat. Res. 36 (3), $283-289$.

Berrang-Ford, L., Pearce, T., Ford, J.D., 2015. Systematic review approaches for climate change adaptation research. Reg. Environ. Change 15 (5), $755-769$.

Biddle, D.-L. (2019, Feb. 20, 2019). Retirement villa deemed flood risk by Thames-Coromandel District Council. Stuff. Retrieved from https://www.stuff.co.nz/ national/110693313/retirement-villa-deemed-flood-risk-by-thames-coromandel-district-council.

Biesbroek, G.R., Klostermann, J., Termeer, C.J.A.M., Kabat, P., 2011. Barriers to climate change adaptation in the Netherlands. Clim. Law 2 (2), 181-199. https://doi. org/10.3233/cl-2011-033.

Biesbroek, G.R., Klostermann, J., Termeer, C.J.A.M., Kabat, P., 2013. On the nature of barriers to climate change adaptation. Reg. Environ. Change 13 (5), $1119-1129$. https://doi.org/10.1007/s10113-013-0421-y.

Biesbroek, G.R., Termeer, C.J.A.M., Klostermann, J.E.M., Kabat, P., 2014a. Analytical lenses on barriers in the governance of climate change adaptation. Mitig. Adapt. Strat. Glob. Change 19 (7), 1011-1032. https://doi.org/10.1007/s11027-013-9457-z.

Biesbroek, G.R., Termeer, C.J.A.M., Klostermann, J.E.M., Kabat, P., 2014b. Rethinking barriers to adaptation: Mechanism-based explanation of impasses in the governance of an innovative adaptation measure. Global Environ. Change 26, 108-118. https://doi.org/10.1016/j.gloenvcha.2014.04.004.

Birkland, T. A. (2016a). Agenda Setting and the Policy Process: Focusing Events. In Oxford Research Encyclopedia of Politics.

Birkland, T. A. (2016b). Policy process theory and natural hazards. In Oxford Research Encyclopedia of Natural Hazard Science.

Boston, J., Lawrence, J., 2018. Funding Climate Change Adaptation: the case for a new policy framework. Policy Quarterly 14 (2).

Braun, V., Clarke, V., 2014. Thematic analysis. In: Encyclopedia of quality of life and well-being research. Springer, pp. 6626-6628.

Burch, S., 2010. Transforming barriers into enablers of action on climate change: Insights from three municipal case studies in British Columbia, Canada. Global Environ. Change 20 (2), 287-297.

Cash, D.W., Clark, W.C., Alcock, F., Dickson, N.M., Eckley, N., Guston, D.H., Mitchell, R.B., 2003. Knowledge systems for sustainable development. Proc. Natl. Acad. Sci. 100 (14), 8086-8091. https://doi.org/10.1073/pnas.1231332100.

CCATWG, 2018. Adapting to Climate Change in New Zealand. Retrieved from Wellington, NZ: https://www.mfe.govt.nz/sites/default/files/media/Climate\% 20Change/ccatwg-report-web.pdf.

Collins, M., Sutherland, M., Bouwer, L., Cheong, S.-M., Frölicher, T., Jacot Des Combes, H., ... Tibig, L. (2019). Extremes, Abrupt Changes and Managing Risk. In H.O. Pörtner, D. C. Roberts, V. Masson-Delmotte, P. Zhai, M. Tignor, E. Poloczanska, K. Mintenbeck, A. Alegría, M. Nicolai, A. Okem, J. Petzold, B. Rama, \& W. NM (Eds.), IPCC Special Report on the Ocean and Cryosphere in a Changing Climate In press.

Corbett, E., Bendall, S., 2019. Clifton to Tangoio Coastal Hazards Strategy 2120, Hawke's Bay, New Zealand. Responding to Rising Seas: OECD Country Approaches to Tackling Coastal Risks. OECD Publishing, Paris.

Cvitanovic, C., Howden, M., Colvin, R., Norström, A., Meadow, A.M., Addison, P., 2019. Maximising the benefits of participatory climate adaptation research by understanding and managing the associated challenges and risks. Environ. Sci. Policy 94, 20-31.

Davison, I. (2011, 28.12.2011). Holiday poll rates north the best. The New Zealand Herald. Retrieved from http://www.nzherald.co.nz/coromandel/news/article. cfm?1_id=123\&objectid=10775557.

Dovers, S., Hezri, A.A., 2010. Institutions and policy processes: the means to the ends of adaptation. WIRESClimate Change 1 (2), $212-231$.

Duijnhoven, H., \& Neef, M. (2016). Disentangling Wicked Problems: A Reflexive Approach Towards Resilience Governance. Applications of Systems Thinking \& Soft Operations Research in Managing Complexity, 91.

Eisenack, K., Moser, S., Hoffmann, E., Klein, R.J.T., Oberlack, C., Pechan, A., Termeer, C.J.A.M., 2014. Explaining and overcoming barriers to climate change adaptation. Nature Clim. Change 4 (10), 867-872.

Fazey, I., Wise, R.M., Lyon, C., Câmpeanu, C., Moug, P., Davies, T.E., 2016. Past and future adaptation pathways. Clim. Dev. 8 (1), 26-44. https://doi.org/10.1080/ 17565529.2014.989192.

Glavovic, B., Kelly, M., Kay, R., Travers, A., 2014. Climate change and the coast: building resilient communities. CRC Press.

Haverkamp, J.A., 2017. Politics, values, and reflexivity: The case of adaptation to climate change in Hampton Roads, Virginia. Environ. Plann. A: Econ. Space 49 (11), 2673-2692. https://doi.org/10.1177/0308518x17707525.

IAP2. (2018). IAP2 Spectrum of Public Participation. Retrieved from https://cdn.ymaws.com/www.iap2.org/resource/resmgr/pillars/Spectrum_8.5x11_Print.pdf.

IPCC. (2012). Managing the Risks of Extreme Events and Disasters to Advance Climate Change Adaptation. A Special Report of Working Groups I and II of the Intergovernmental Panel on Climate Change. In C. B. Field, V. Barros, T. F. Stocker, D. Qin, D. J. Dokken, K. L. Ebi, M. D. Mastrandrea, K. J. Mach, G. K. Plattner, S. K. Allen, M. Tignor, \& P. M. Midgley (Eds.). Cambridge, UK, and New York, NY, USA: Cambridge University Press.

IPCC. (2019). Choices made now are critical for the future of our ocean and cryosphere [Press release]. Retrieved from https://www.ipcc.ch/2019/09/25/srocc-pressrelease/.

Juhola, S., 2016. Barriers to the implementation of climate change adaptation in land use planning: A multi-level governance problem? Int. J. Clim. Change Strategies Manage. 8 (3), 338-355.

Kench, P., Ryan, E., Owen, S., Bell, R., Lawrence, J., Glavovic, B., Allis, M., 2018. Co-creating Resilience Solutions to Coastal Hazards Through an Interdisciplinary Research Project in New Zealand. J. Coastal Res. 85 (sp1), 1496-1500.

Klein, R. J. T., Midgley, G. F., Preston, B. L., Alam, M., Berkhout, F. G. H., Dow, K., \& Shaw, M. R. (2014). Adaptation opportunities, constraints, and limits. In C. B. Field, V. R. Barros, D. J. Dokken, K. J. Mach, M. D. Mastrandrea, T. E. Bilir, M. Chatterjee, K. L. Ebi, Y. O. Estrada, R. C. Genova, B. Girma, E. S. Kissel, A. N. Levy, S. MacCracken, P. R. Mastrandrea, \& L. L. White (Eds.), Climate Change 2014: Impacts, Adaptation, and Vulnerability. Part A: Global and Sectoral Aspects. Contribution of Working Group II to the Fifth Assessment Report of the Intergovernmental Panel on Climate Change (pp. 899-943). Cambridge, UK and New York, NY, USA: Cambridge University Press.

Komar, P.D., 2010. Shoreline evolution and management of Hawke's Bay, New Zealand: Tectonics, coastal processes, and human impacts. J. Coastal Res. 261 (1), 143-156.

Komar, P. D., \& Harris, E. (2014). Hawke's Bay, New Zealand: Global Climate Change and Barrier-Beach Responses. Retrieved from https://www.hbcoast.co.nz/ assets/Document-Library/Technical-Documents/Hawkes-Bay-Summary-Report.pdf.

Kooiman, J., 2003. Governing as Governance. Sage, London.

Lawrence, J., Bell, R., Blackett, P., Ryan, E., \& Robichaux, L. (2019). A Practice Brief: From Guidance to Practice-The adaptation transition at the coast. Planning Quarterly, September 2019(214).

Lawrence, J., Bell, R., Blackett, P., Stephens, S., Allan, S., 2018. National guidance for adapting to coastal hazards and sea-level rise: Anticipating change, when and how to change pathway. Environ. Sci. Policy 82, 100-107.

Lawrence, J., Bell, R., Stroombergen, A., 2019b. A hybrid process to address uncertainty and changing climate risk in coastal areas using dynamic adaptive pathways planning, multi-criteria decision analysis \& real options analysis: a New Zealand application. Sustainability 11 (2), 406.

Lawrence, J., Sullivan, F., Lash, A., Ide, G., Cameron, C., McGlinchey, L., 2015. Adapting to changing climate risk by local government in New Zealand: institutional practice barriers and enablers. Local Environment 20 (3), 298-320. https://doi.org/10.1080/13549839.2013.839643.

Le Heron, E., Logie, J., Allen, W., Le Heron, R., Blackett, P., Davies, K., Hikuroa, D., 2019. Diversity, contestation, participation in Aotearoa New Zealand's multi-use/ user marine spaces. Marine Policy 106, 103536. https://doi.org/10.1016/j.marpol.2019.103536. 
Lemos, M.C., Kirchhoff, C.J., Ramprasad, V., 2012. Narrowing the climate information usability gap. Nat. Clim. Change 2 (11), 789-794. https://doi.org/10.1038/ nclimate1614.

Manning, M., Lawrence, J., King, D.N., Chapman, R., 2015. Dealing with changing risks: a New Zealand perspective on climate change adaptation. Reg. Environ. Change 15 (4), 581-594.

MFE, 2017. Coastal hazards and climate change: Guidance for local government. Retrieved from Wellington: http://www.mfe.govt.nz/publications/climate-change/ coastal-hazards-and-climate-change-guidance-local-government.

Monin, P., 2012. Hauraki-Coromandel places - Mercury Bay. Retrieved from. http://www.teara.govt.nz/en/hauraki-coromandel-places/page-6.

Moser, S.C., 2013. Navigating the political and emotional terrain of adaptation: community engagement when climate change comes home. In: Moser, S.C., Boykoff, M.T. (Eds.), Successful Adaptation to Climate Change. Routledge, pp. 289-305.

Moser, S.C., Ekstrom, J.A., 2010. A framework to diagnose barriers to climate change adaptation. Proc. Natl. Acad. Sci. 107 (51), $22026-22031$.

Naess, L., Bang, G., Eriksen, S., Vevatne, J., 2005. Institutional adaptation to climate change: flood responses at the municipal level in Norway. Global Environ. Change 15 (2), 125-138.

Oberlack, C., 2017. Diagnosing institutional barriers and opportunities for adaptation to climate change. Mitig. Adapt. Strat. Glob. Change 22 (5), 805-838. https:// doi.org/10.1007/s11027-015-9699-z.

OECD. (2019). Clifton to Tangoio Coastal Hazards Strategy 2120, Hawke's Bay, New Zealand. In Responding to Rising Seas: OECD Country Approaches to Tackling Coastal Risks (pp. 137-154). Paris: OECD Publishing.

Oppenheimer, M., Glavovic, B.C., Hinkel, J., van de Wal, R., Magnan, A.K., Abd-Elgawad, A., Sebesvari, Z., 2019. Sea Level Rise and Implications for Low-Lying Islands, Coasts and Communities. In: Pörtner, H.-.O., Roberts, D.C., Masson-Delmotte, V., Zhai, P., Tignor, M., Poloczanska, E., Mintenbeck, K., Alegría, A., Nicolai, M., Okem, A., Petzold, J., Rama, B., Weyer, N.M. (Eds.), IPCC Special Report on the Ocean and Cryosphere in a Changing Climate. In Press.

Preston, B.L., Mustelin, J., Maloney, M.C., 2015. Climate adaptation heuristics and the science/policy divide. Mitig. Adapt. Strat. Glob. Change 20 (3), $467-497$.

Reed, M.S., 2008. Stakeholder participation for environmental management: A literature review. Biol. Conserv. 141 (10), 2417-2431. https://doi.org/10.1016/j. biocon.2008.07.014.

Reisinger, A., Lawrence, J., Hart, G., Chapman, R., 2015. From coping to resilience: the role of managed retreat in highly developed coastal regions of New Zealand. In: Glavovic, B., Kaye, R., Kelly, M., Travers, A. (Eds.), Climate Change and the Coast. CRC Press, London.

Reisinger, A., R.L. Kitching, R. L., Chiew, F., Hughes, L., Newton, P. C. D., Schuster, S. S., . . Whetton, P. (2014). Australasia. In V. R. Barros, C. B. Field, D. J. Dokken, M. D. Mastrandrea, K. J. Mach, T. E. Bilir, M. Chatterjee, K. L. Ebi, Y. O. Estrada, R. C. Genova, B. Girma, E. S. Kissel, A. N. Levy, S. MacCracken, P. R. Mastrandrea, \& L. L. White (Eds.), Climate Change 2014: Impacts, Adaptation, and Vulnerability. Part B: Regional Aspects.

RMLA. (2020). Climate change to be included in all council decision making. Retrieved from https://www.rmla.org.nz/2020/07/30/climate-change-to-be-includedin-all-council-decision-making/.

Ropiha, A. (2017). Assessment of Cultural Values Report Retrieved from Napier, NZ:

Rouse, H., Bell, R., Lundquist, C., Blackett, P., Hicks, D., King, D., 2017. Coastal adaptation to climate change in Aotearoa-New Zealand. N. Z. J. Mar. Freshwater Res. 51 (2), 183-222. https://doi.org/10.1080/00288330.2016.1185736.

Royal Society of New Zealand. (2016). Climate change implications for New Zealand. Retrieved from Wellington, NZ: https://www.royalsociety.org.nz/what-we-do/ our-expert-advice/all-expert-advice-papers/climate-change-implications-for-new-zealand/.

Schneider, P., 2014. Local reality and the climate change adaptation dilemma: beyond technical fixes and'business as usual': dissertation presented in partial fulfilment of the requirements for the degree of Doctor of Philosophy in Resource and Environmental Planning at Massey University, Manawatu. Massey University, New Zealand.

Schneider, P., \& Glavovic, B. (2019). Climate Change Adaptation in New Zealand. In Oxford Research Encyclopedia of Natural Hazard Science.

Schneider, P., Glavovic, B., Farrelly, T., 2017. So Close Yet So Far Apart: Contrasting Climate Change Perceptions in Two "Neighboring" Coastal Communities on Aotearoa New Zealand's Coromandel Peninsula. Environments 4 (3), 65.

Serrao-Neumann, S., Crick, F., Harman, B., Schuch, G., Choy, D.L., 2015a. Maximising synergies between disaster risk reduction and climate change adaptation: Potential enablers for improved planning outcomes. Environ. Sci. Policy 50, 46-61. https://doi.org/10.1016/j.envsci.2015.01.017.

Serrao-Neumann, S., Harman, B., Leitch, A., Low Choy, D., 2015b. Public engagement and climate adaptation: insights from three local governments in Australia. J. Environ. Plann. Manage. 58 (7), 1196-1216.

Stancu, C. (2017). Coastal Hazards Social Impact Assessment \& Valuation for Ahuriri/Pandora, Westshore, Bay View and Whirinaki. Retrieved from Napier.

Statistics New Zealand, 2013. 2013 Census QuickStats about a place: Whitianga. Retrieved from. http://archive.stats.govt.nz/Census/2013-census/profile-andsummary-reports/quickstats-about-a-place.aspx?request_value=13633\&parent_id=13632\&tabname=\#13633.

Statistics New Zealand. (2018). Subnational Population Estimates Retrieved from http://statsnz.maps.arcgis.com/apps/webappviewer/index.html? $\mathrm{id}=\mathrm{c} 2 \mathrm{ec} 1 \mathrm{c} 830 \mathrm{e} 5 \mathrm{~b} 4 \mathrm{~b} 5 \mathrm{e} 9644588 \mathrm{bbdb} 4 \mathrm{~b} 74 \mathrm{e}$.

Šnde, C., Sinner, J., Tadaki, M., Stephenson, J., Glavovic, B., Awatere, S., Chan, K., 2018. Valuation as destruction? The social effects of valuation processes in contested marine spaces. Marine Policy 97, 170-178. https://doi.org/10.1016/j.marpol.2018.05.024.

TCDC, 2014. The costs of protecting our coastlines. Retrieved from. http://www.tcdc.govt.nz/Your-Council/News-and-Media/News-and-Public-Notices/NewsArchived-Articles/July-2014/The-costs-of-protecting-our-coastlines/.

TCDC, 2015. Long Term Plan 2015-2025. Retrieved from Thames, New Zealand: http://www.tcdc.govt.nz/Download/?file=/Global/FINAL\%20Long\%20Term\% 20Plan\%20as\%20at\%2013th\%20July\%2015.pdf.

TCDC, 2016. Communities and Wards. Retrieved from. https://www.tcdc.govt.nz/Your-Council/Communities-and-Wards/.

TCDC, 2019a. Protecting our coast. Retrieved from. https://www.tcdc.govt.nz/Your-Council/Documents-incl-Bylaws-Policies-and-Strategies/Coastal-ManagementStrategy/.

TCDC, 2019b. Shorelione Management Plans. Retrieved from Latest News \& Public Notices.

Termeer, C.J.A.M., Dewulf, A., Biesbroek, G.R., 2017. Transformational change: governance interventions for climate change adaptation from a continuous change perspective. J. Environ. Plann. Manage. 60 (4), 558-576. https://doi.org/10.1080/09640568.2016.1168288.

Termeer, C. J. A. M., Dewulf, A., Karlsson-Vinkhuyzen, S. I., Vink, M., \& Vliet, M. v. (2016). Coping with the wicked problem of climate adaptation across scales: The Five R Governance Capabilities. Landscape Urban Plann., 154, 11-19. doi:https://doi.org/10.1016/j.landurbplan.2016.01.007.

Termeer, C.J.A.M., Dewulf, A., Van Rijswick, H., Van Buuren, A., Huitema, D., Meijerink, S., Wiering, M., 2011. The regional governance of climate adaptation: a framework for developing legitimate, effective, and resilient governance arrangements. Clim. Law 2 (2), $159-179$.

Tobin, G.A., 1995. The Levee Love Affair: A Stormy Relationship? JAWRA J. Am. Water Resour. Association 31 (3), 359-367. https://doi.org/10.1111/j.17521688.1995.tb04025.x.

Uittenbroek, C.J., Mees, H.L.P., Hegger, D.L.T., Driessen, P.P.J., 2019. The design of public participation: who participates, when and how? Insights in climate adaptation planning from the Netherlands. J. Environ. Plann. Manage. 62 (14), 2529-2547. https://doi.org/10.1080/09640568.2019.1569503.

Viner, D., Ekstrom, M., Hulbert, M., Warner, N.K., Wreford, A., Zommers, Z., 2020. Understanding the dynamic nature of risk in climate change assessments-A new starting point for discussion. Atmos. Sci. Lett. n/a(n/a), e958 https://doi.org/10.1002/asl.958.

Walker, B.J.A., Adger, W.N., Russel, D., 2014. Institutional barriers to climate change adaptation in decentralised governance structures: Transport planning in England. Urban studies 52 (12), 2250-2266. https://doi.org/10.1177/0042098014544759.

Waters, E., \& Barnett, J. (2017). Spatial imaginaries of adaptation governance: A public perspective. Environ. Plann.C: Politics and Space, 0(0), 2399654417719557. doi:10.1177/2399654417719557.

Waters, E., Barnett, J., Puleston, A., 2014. Contrasting perspectives on barriers to adaptation in Australian climate change policy. Clim. Change 124 (4), 691-702. https://doi.org/10.1007/s10584-014-1138-8.

Westling, E.L., Sharp, L., Scott, D., Tait, S., Rychlewski, M., Ashley, R.M., 2019. Reflexive adaptation for resilient water services: Lessons for theory and practice. Global Environ. Change 57, 101937. https://doi.org/10.1016/j.gloenvcha.2019.101937. 